\title{
OPEN Diffusible signal factor signaling controls bioleaching activity and niche protection in the acidophilic, mineral-oxidizing leptospirilli
}

\author{
Sören Bellenberg ${ }^{1 凶}$, Beatriz Salas ${ }^{2}$, Suresh Ganji ${ }^{3}$, Cristian Jorquera-Román ${ }^{4}$, \\ Maria Luisa Valenzuela ${ }^{5}$, Antoine Buetti-Dinh ${ }^{6,7}$, C. Rikard Unelius ${ }^{3}$, Mark Dopson ${ }^{1}$ \& \\ Mario Vera ${ }^{2,4 凶}$
}

Bioleaching of metal sulfide ores involves acidophilic microbes that catalyze the chemical dissolution of the metal sulfide bond that is enhanced by attached and planktonic cell mediated oxidation of iron(II)-ions and inorganic sulfur compounds. Leptospirillum spp. often predominate in sulfide mineral-containing environments, including bioheaps for copper recovery from chalcopyrite, as they are effective primary mineral colonizers and oxidize iron(II)-ions efficiently. In this study, we demonstrated a functional diffusible signal factor interspecies quorum sensing signaling mechanism in Leptospirillum ferriphilum and Leptospirillum ferrooxidans that produces (Z)-11-methyl-2-dodecenoic acid when grown with pyrite as energy source. In addition, pure diffusible signal factor and extracts from supernatants of pyrite grown Leptospirillum spp. inhibited biological iron oxidation in various species, and that pyrite grown Leptospirillum cells were less affected than iron grown cells to self inhibition. Finally, transcriptional analyses for the inhibition of iron-grown L. ferriphilum cells due to diffusible signal factor was compared with the response to exposure of cells to $\mathrm{N}$ - acyl-homoserinelactone type quorum sensing signal compounds. The data suggested that Leptospirillum spp. diffusible signal factor production is a strategy for niche protection and defense against other microbes and it is proposed that this may be exploited to inhibit unwanted acidophile species.

The industrial process of biomining describes the use of acidophilic microbes for the recovery of metals from sulfide ores. It includes bioleaching when the target metal is part of the metal sulfide mineral and biooxidation when the target metal is trapped as microscopic particles within the mineral matrix. Both processes are mediated by chemical dissolution of the metal sulfide bond that is enhanced by microbial oxidation of iron(II)-ions and inorganic sulfur compounds (ISCs). ISC oxidation to sulfuric acid contributes to the generation of an acidic medium while iron(II)-ion oxidation regenerates iron(III) ions, the chemical oxidant of the metal sulfide bond ${ }^{1,2}$. Acidophilic bacteria of the genera Acidithiobacillus, Leptospirillum, Acidiphilium, and Sulfobacillus are often present in sulfide mineral-containing environments between approximately $20-40{ }^{\circ} \mathrm{C}$. For instance, Leptospirillum spp. often predominate in sulfide mineral-containing environments ${ }^{3-6}$ as they oxidize iron(II)-ions efficiently at

\footnotetext{
${ }^{1}$ Centre for Ecology and Evolution in Microbial Model Systems (EEMiS), Linnaeus University, Kalmar, Sweden. ${ }^{2}$ Department of Hydraulic and Environmental Engineering, Pontificia Universidad Católica de Chile, Av. Vicuña Mackenna 4860, Macul, 7820486 Santiago, Chile. ${ }^{3}$ Department of Chemistry and Biomedical Sciences,

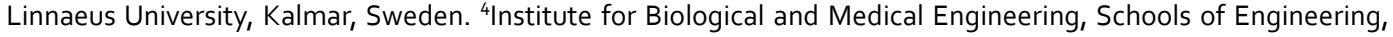
Medicine and Biological Sciences, Pontificia Universidad Católica de Chile, Av. Vicuña Mackenna 4860, Macul, 7820486 Santiago, Chile. ${ }^{5}$ Grupo de Investigación en Energía y Procesos Sustentables, Facultad de Ingeniería, Instituto de Ciencias Químicas Aplicadas, Universidad Autónoma de Chile, Av. El Llano Subercaseaux 2801, San Miguel, Santiago de Chile, Chile. '6aboratory of Applied Microbiology (LMA), Department of Environment, Constructions and Design (DACD), University of Applied Sciences of Southern Switzerland (SUPSI), Via Mirasole 22a, 6500 Bellinzona, Switzerland. ${ }^{7}$ Swiss Institute of Bioinformatics, Quartier Sorge - Batiment Genopode, 1015 Lausanne, Switzerland. ${ }^{\circledR}$ email: soeren.bellenberg@uni-due.de; mariovera@uc.cl
} 
high iron(III)/iron(II)-ion ratios ${ }^{7,8}$. Consequently, Leptospirillum ferriphilum often represents a significant portion of the microbial community in bioheaps for copper recovery from chalcopyrite $\left(\mathrm{CuFeS}_{2}\right)$, the most abundant copper containing metal sulfide in the world 9 .

Cell attachment and biofilm formation on ores is mediated by extracellular polymeric substances (EPS) and is considered a critical process for mineral dissolution ${ }^{2,10,11}$. Attached cells on sulfidic ores significantly influence the dissolution kinetics ${ }^{12,13}$, and the degree of cell attachment to pyritic ores by iron oxidizing acidithiobacilli can be manipulated by pre-cultivation conditions, nutritional supplementation, $\mathrm{pH}$, and ionic strength of the medium $^{14}$. Leptospirillum species are efficient biofilm forming strains on pyrite and chalcopyrite ${ }^{15}$ due to high amounts of EPS embedding attached cells to the mineral surface ${ }^{12,16,17}$. However, it is unknown if other factors may influence mineral colonization by Leptospirillum, making them crucial for understanding cell attachment and biofilm formation on metal sulfides.

Quorum sensing (QS) comprises several types of cell-cell communication mechanisms mediated by the secretion of small 'autoinducer' molecules that regulate gene expression in a cell-density-dependent manner ${ }^{18}$. Acidophile LuxI/R type QS systems are present in several strains of Acidithiobacillus ferrooxidans, Acidithiobacillus thiooxidans, and Acidiferrobacter spp. ${ }^{19,20}$. In addition, synthetic $\mathrm{N}$-acyl homoserine lactones (AHLs) modulate EPS production and biofilm formation in several acidophilic leaching bacteria ${ }^{19-25}$. However, Leptospirillum ferrooxidans, L. ferriphilum, and Acidithiobacillus ferrivorans lack AHL synthesis genes ${ }^{20}$. However they respond to external AHL addition, most likely due to the presence of orphan LuxR-like receptors ${ }^{20,26}$. Acidophiles also possess a cyclic diguanylate (c-di-GMP) signaling system that is synthesized in Gram-negative bacteria by several proteins with diguanylate cyclase activity (DGC) and degraded by phosphodiesterase (PDE) domain containing proteins. Intracellular c-di-GMP levels control several phenotypes such as chemotaxis, motility, EPS production, and biofilm formation ${ }^{27}$. QS and c-di-GMP are proposed to be the principal mechanisms regulating biofilm formation and EPS biosynthesis in Gram-negative acidophiles ${ }^{28,29}$. Furthermore, the presence of c-di-GMP metabolism in acidithiobacilli, L. ferrooxidans, and Acidiferrobacter sp. SPIII/3 and the increase of c-di-GMP levels measured in At. ferrooxidans ATCC $23270^{\mathrm{T}}$ cells adhering to solid substrates suggests a connection between AHL mediated QS and the c-di-GMP pathways ${ }^{20,24,26,30,31}$. Another type of QS based system relies on diffusible signal factors (DSF) from a family of cis-2-unsaturated fatty acid signal compounds and DSF family signal sensing is known to act directly on c-di-GMP metabolism ${ }^{32,33}$. The main compounds identified are DSF ((Z)-11-methyl-2-dodecenoic acid) and Burkholderia diffusible signal factor (BDSF, (Z)-2-dodecenoic acid). Furthermore, DSF-signaling is associated with a strong inter-species and even inter-kingdom biofilm dispersal activity ${ }^{32,34-37}$. A complete DSF system is coded on the L. ferriphilum DSM $14647^{\mathrm{T}}$ genome including DSF synthase ( $r p f F$, LFTS_00514), a Hpt domain containing protein (LFTS_00515) adjacent to a signal transduction sensor kinase homologue ( $r p f C$, LFTS_00516), and the respective two-component system response regulator encoding genes $r p f G$ (LFTS_00517) ${ }^{15,38}$. DSF synthesis (RpfF) plus signaling and transduction (RpfC and RpfG) are mediated via the PDE HD-GYP domain of RpfG. Hence, lowered levels of c-di-GMP in the presence of DSF are thought to mediate biofilm dispersal and stimulate motility. Increased $r p f$ gene RNA transcripts are present in continuous iron(II) cultures and in batch chalcopyrite cultures ${ }^{39}$ and the DSF synthase is enhanced in the planktonic population in axenic and mixed cultures ${ }^{15}$. L. ferrooxidans C2-3 exhibits a similar rpf gene cluster with a complete $r p f C$ homologue ${ }^{40}$. In addition, the genomes of both Leptospirillum species encode multiple $r p f R$ candidate genes. RpfR inhibits DSF synthase RpfF activity, unless DSF binds at RpfR PAS domain, causing conformational changes that release it from RpfF and trigger its PDE activity. A similar regulatory interaction with RpfF has been described for $\mathrm{RpfC}^{32}$. Consequently, we hypothesize that Leptospirillum species produce DSF-family signal molecules and that they are involved in regulating biofilm formation and bioleaching of metal sulfide ores.

Understanding microbial interactions with mineral surfaces along with inter- and intra-species cell-to-cell communication mechanisms are highly relevant for developing strategies to improve biomining. Recently, it was demonstrated that DSF and BDSF signal compounds have a strong inhibitory effect on the metabolic activity of bioleaching bacteria and their biofilm forming capabilities ${ }^{15}$. In this study, we test the hypothesis that DSF production by Leptospirillum spp. is a strategy for niche protection and defense against other bioleaching microbes and if this phenotype may be exploited in biomining to inhibit unwanted acidophile species.

\section{Results}

Presence of DSF-family compounds in cultures of $L$. ferrooxidans and L. ferriphilum. The organization of the rpfFCG gene clusters of both species is shown in Fig. 1. The DSF gene cluster of L. ferriphilum DSM $14647^{\mathrm{T}}$ includes DSF synthase encoding gene $r p f F$, two genes encoding $r p f C$ homologs. These are annotated as a "Hpt domain-containing protein", and "signal transduction kinase", encoding the receiver and the histidine phosphotranfer domains of RpfC and the phosphoacceptor domain histidine kinase A plus the histidine kinase like ATPase domain of $\mathrm{RpfC}$, respectively. Also the two-component system response regulator-encoding gene $r p f G$ is located in this gene cluster. L. ferrooxidans C2-3 exhibits a similar $r p f$ gene cluster structure, with a complete $r p f C$ homologue, encoding all the corresponding domains in the same annotated protein, located at a slightly longer distance from $r p f F$ than other compared genomes. Other identified $r p f$ homolog genes, in particular $r p f R$ candidates, are encoded in different genomic locations, outside the $r p f F C G$ cluster (Supplemental Fig $\mathrm{S} 1$ ). In Xanthomonas campestris, the genes encoding RpfC and RpfG are organized in an operon that is convergently transcribed to $r p f F$. This operon also contains $r p f H$, which encodes a protein similar to the input domain of RpfC, but with unknown function. The $r p f F$ gene is found in an operon with $r p f B$, which encodes a fatty acylCoA ligase that may be involved in DSF processing. This organization of $r p f$ genes occurs in all xanthomonads with the variation that $r p f H$ is not widely conserved as seen for Xanthomonas oryzae. In Burkholderia species, the RpfFR system is widely conserved, where both genes $r p f F$ and $r p f R$ are convergently transcribed, whereas the genome of B. cenocepacia possess two flanking genes, BCAM0227 and BCAM0228, which encodes an "acces- 
Xanthomonas campestris

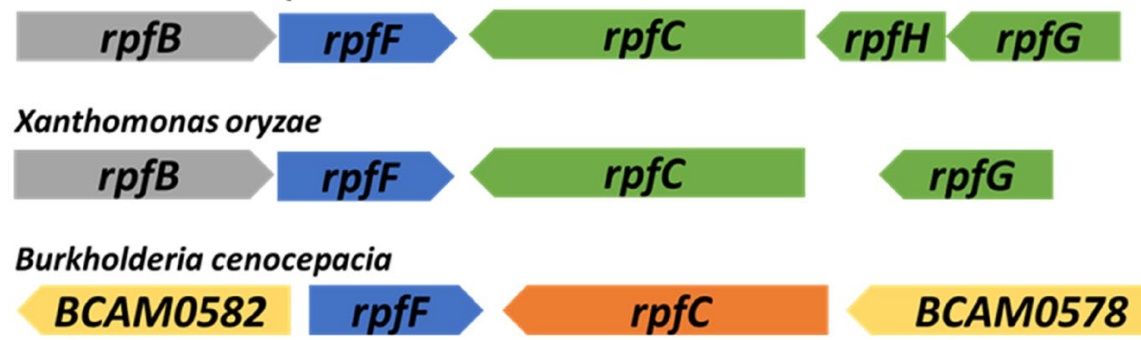

Leptospirillum ferriphilum ${ }^{\top}$

rpfF

hpt $r p f C$ $r p f G$

Leptospirillum ferrooxidans C2-3

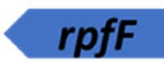

\section{.} $r p f C$

$r p f G$

Figure 1. Organization of the rpf gene clusters in the genomes of L. ferriphilum ${ }^{\mathrm{T}}$ and L. ferrooxidans C2-3. Gene clusters encoding the proteins of the DSF family QS systems have been compared with the model organisms Burkholderia cenocepacia, and two species of Xanthomonas; X. campestris and X. oryzae.

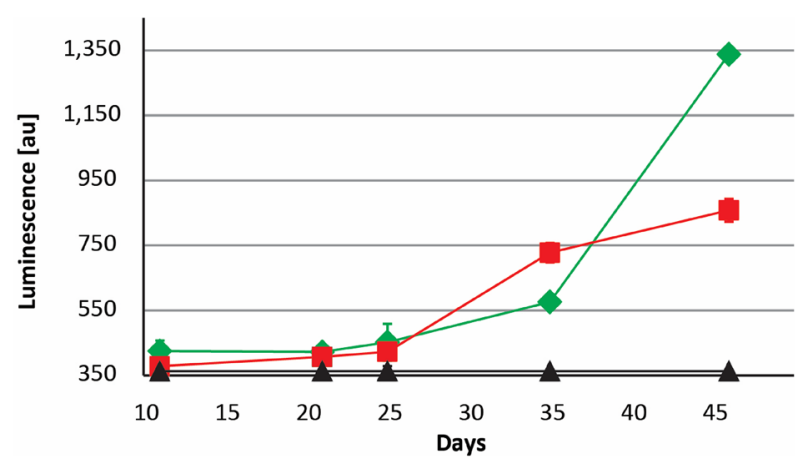

Figure 2. Bioassay for detection of BDSF and DSF in Leptospirillium spp. extracts cultured on pyrite. The black line and triangles indicate luminescence levels observed in control samples. The green line and diamonds or red line and boxes indicate luminescence levels in assays with extracts from L. ferriphilum ${ }^{\mathrm{T}}$ or L. ferrooxidans ${ }^{\mathrm{T}}$, respectively. Data are averages $\pm \mathrm{SD}$ of luminescence reads from triplicate experiments $(n=3)$.

sory" system involved in BDSF signal transduction and response regulation, respectively. The flanking genes of DSF clusters in L. ferriphilum and L. ferrooxidans are unrelated, and showed no significant identity values to the known flanking genes of Burkholderia and Xanthomonas.

The biosensor strain Burkholderia cenocepacia H111-rpfF $F_{B c}$ (pan-L15) was used to confirm that DSF and BDSF could be efficiently extracted from acidic culture medium in pyrite cultures using dichloromethane (Supplemental Fig. S2). As previously described ${ }^{41}$, the biosensor was more sensitive for detecting BDSF than DSF and a semi-quantitative estimation was possible for pure synthetic substances (Supplemental Fig. S3). DSFfamily compounds were found in batch pyrite cultures of both Leptospirillum species, especially at later stages after 25 days of cultivation when an elevated luminescence suggested that DSF family molecules accumulated in pyrite culture supernatants (Fig. 2). Extracts from $500 \mathrm{~mL}$ stationary phase iron(II)-grown cultures did not trigger luminescence of the biosensor (not shown) while extracts from pyrite grown L. ferriphilum cells inhibited cell growth and iron oxidation in cultures of Acidiferrobacter SPIII/3 and L. ferrooxidans. (Supplemental Fig. S4).

Analysis of DSF production by L. ferrooxidans and L. ferriphilum ${ }^{\top}$. Comparison of retention times of synthetic DSF in gas chromatography with peaks in culture extracts and the characteristic fragmentation patterns of these peaks in gas chromatography-mass spectrometry (GC-MS) unambiguously identified the presence of biogenic DSF in cultures of both Leptospirillum species (Fig. 3), although with differing development profiles (Fig. 4). Namely, the DSF concentration in L. ferrooxidans pyrite cultures increased from $4.1 \pm 0.8 \mathrm{nM}$ (all $n=3$ ) on day 11 to a plateau at $6.4 \pm 0.2 \mathrm{nM}$ on day 25 and remained constant. In contrast, L. ferriphilum ${ }^{\mathrm{T}}$ pyrite cultures had a low and constant DSF level at $3.2 \pm 0.2$ and $3.2 \pm 0.3 \mathrm{nM}$ on days 11 to 21 followed by an increase to $6.6 \pm 1.2 \mathrm{nM}$ on day 35 and $7.5 \pm 1.9 \mathrm{nM}$ on day 46 . 

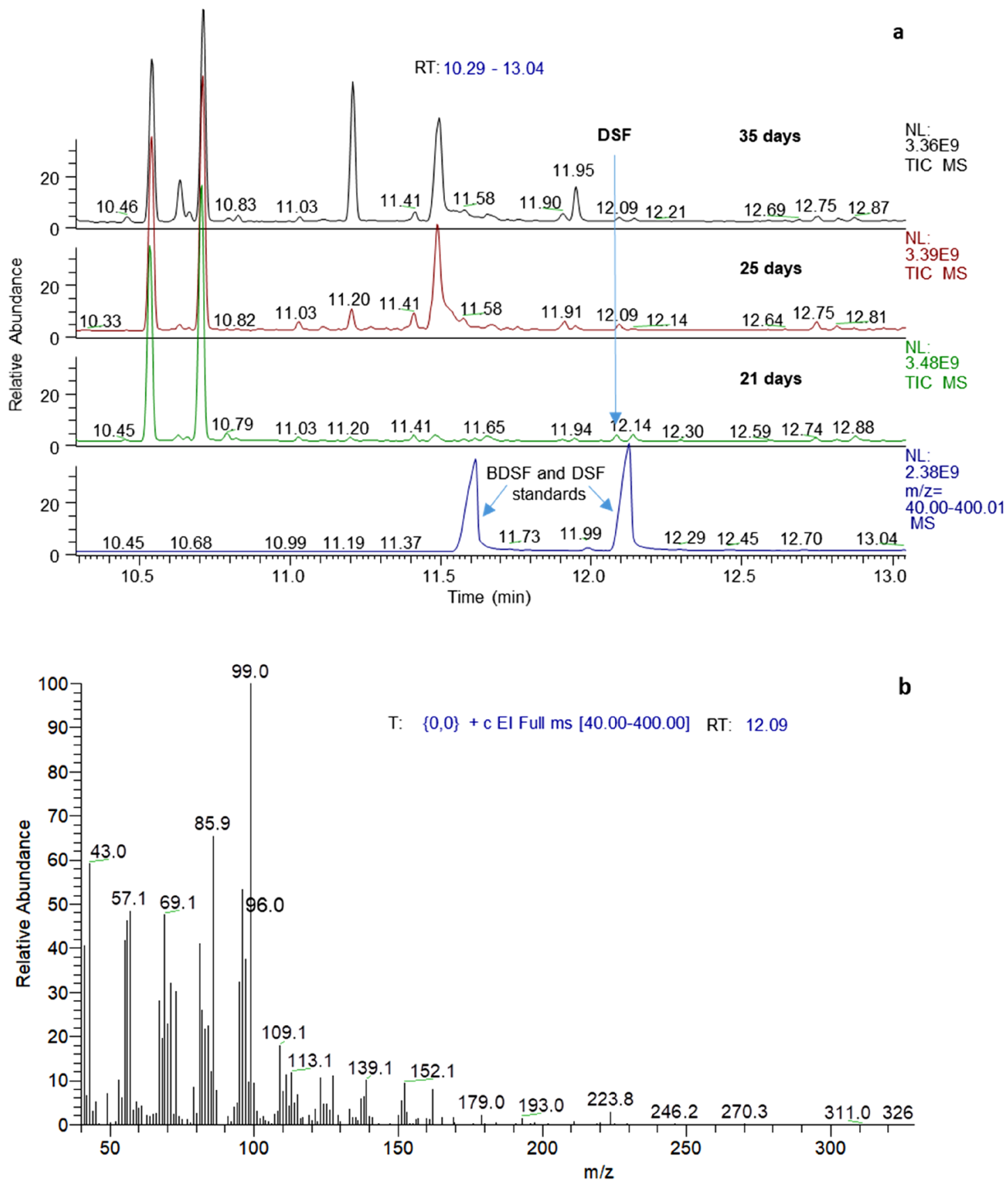

Figure 3. GC-MS analysis of culture extracts for identification of biogenic DSF. Total ion chromatograms of extracts from 21, 25, and 35 days old L. ferrooxidans ${ }^{\mathrm{T}}(\mathbf{a})$ and L. ferriphilum $\operatorname{DSM}^{\mathrm{T}}$ (c) pyrite cultures measured by GC-MS. The mass spectrum at the inferred retention time of DSF (12.09 min) confirmed the presence of the biogenic substance in pyrite culture supernatants of L. ferrooxidans ${ }^{\mathrm{T}}(\mathbf{b})$ and L. ferriphilum ${ }^{\mathrm{T}}(\mathbf{d})$. 


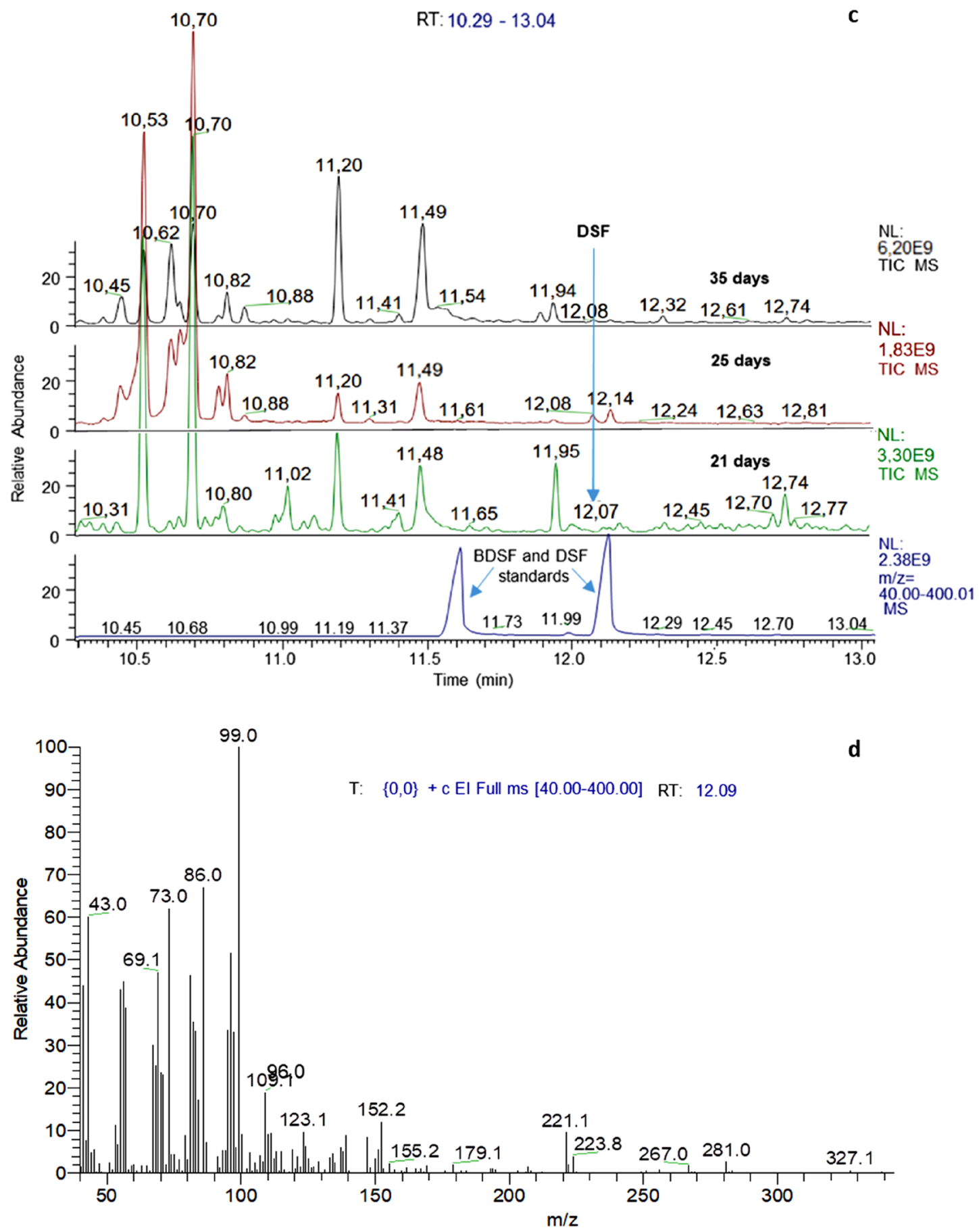

Figure 3. (continued)

Physiological effects of synthetic DSF and BDSF on growth and iron oxidation. Iron(II)-grown cells of all the strains used in this study were inhibited regarding their ability to oxidize iron(II)-ions by exposure to $5 \mu \mathrm{M}$ DSF or BDSF. For instance, L. ferriphilum ${ }^{\mathrm{T}}$ iron(II) oxidation was delayed after exposure to $5 \mu \mathrm{M}$ DSF or BDSF (Fig. 5) and once the inhibition was overcome, the rate of iron oxidation was significantly lower (Welch $\mathrm{t}$-test, $p=0.0029)$ at $0.40 \pm 0.03 \mathrm{mmol} / \mathrm{h}$ as compared to the control assay or after exposure to $1 \mu \mathrm{M}$ effector compounds $(0.91 \pm 0.08 \mathrm{mmol} / \mathrm{h})$. In consequence, both the growth rate and cell yield were significantly lower after exposure to $5 \mu \mathrm{M}$ DSF or BDSF (Fig. 5b).

DSF and BDSF were also tested in combination at $0.1,1$, and $5 \mu \mathrm{M}$ per compound that resulted in combined concentrations of $0.2,2$, and $10 \mu \mathrm{M}$ DSF-family compounds (Fig. 6). The effects of $10 \mu \mathrm{M}$ addition were more pronounced (e.g. an initial cell lysis; Fig. 6c) when using a lower inoculum size $\left(4 \times 10^{6}\right.$ cells $\left./ \mathrm{mL}\right)$ and hence, a higher relative concentration of DSF or BDSF per cell. Cell growth in assays with iron(II)-grown cells followed the trend of iron oxidation. Delayed iron(II) oxidation was observed with $0.2 \mu \mathrm{M}$, while iron oxidation did not 
occur within $150 \mathrm{~h}$ at 2 and $10 \mu \mathrm{M}$. Iron(II)-grown cells of $L$. ferriphilum were more sensitive to the presence of DSF and BDSF than pyrite-grown cells. For instance, the latter were unaffected in presence of $0.2 \mu \mathrm{M}$ DSF family compound and iron oxidation was observed $100 \mathrm{~h}$ after inoculation in assays with $2 \mu \mathrm{M}$.

Similar qualitative effects regarding cell growth (not shown) and iron oxidation were observed with iron(II)grown cells of $L$. ferrooxidans ${ }^{\mathrm{T}}$ and with members of other bacterial phyla, such as At. ferrooxidans ATCC 53993, Acidithiobacillus ferridurans ATCC $33020^{\mathrm{T}}$, Acidiferrobacter sp. SPIII/3 DSM 27195, and Sulfobacillus thermosulfidooxidans DSM $9293^{\mathrm{T}}$ (Fig. 7).

Effect of DSF-family and AHL- signal compounds on iron(II)-grown L. ferriphilum ${ }^{\top}$ RNA transcripts. Analysis of RNA transcripts after exposure of iron(II)-grown cells of L. ferriphilum ${ }^{\mathrm{T}}$ to DSF and BDSF revealed 100 genes with significantly differing transcript numbers $\left(\mid \log _{2}\right.$-fold change (LFC) $\mid>1, p$ value $<0.05$; Supplemental Table S1). The majority (92 of 100) of these genes were significantly decreased and were associated with respiration, central carbon metabolism, biosynthesis of amino acids, iron-sulfur clusters, cytochromes, nucleotides, vitamins, lipopolysaccharides, cell walls, and flagella (Supplemental Table S1). Six of the eight genes with increased RNA transcript counts when exposed to DSF/BDSF encoded proteins were annotated as components of multidrug efflux systems (LFTS_00939 -_00941,_02071 - _02073). The toxic effect of DSF/BDSF was also supported by the functional annotation of those genes by COG analysis (Fig. 8a). Three of those genes with increased transcripts were categorized in COG V (defense mechanisms; LFTS_00941,_02072,_02073), two were multidrug-export membrane proteins in COG M (cell wall/membrane synthesis, LFTS_02071,_02073), and one was a related transcriptional regulator COG K (transcription, LFTS_00939), located within the putative operon structure of one of the multidrug efflux systems (LFTS_00939 -_00941). The remaining two genes (LFTS_01634 and_01845) were annotated as trehalose 6-phosphate phosphatase (otsB) and diguanylate cyclase (GGDEF) domain-containing protein $(\operatorname{dos} C)$, respectively.

Analysis of the transcriptomes after two hours of treatment with the AHL mixture resulted in 419 statistically different expressed transcripts $(|\mathrm{LFC}|>1, p$ value $<0.05)$ of which 206 and 213 transcripts were increased and decreased, respectively (Supplemental Table S2 shows a sub-set of transcripts with $\mid$ LFC $\mid>2$, $p$ value $<0.005$ ). Transcripts with decreased counts included genes in the COG categories translation (J), intracellular trafficking and secretion (U), signal transduction $(\mathrm{T})$, and cell motility $(\mathrm{N})$, respectively (Fig. 8b). Transcripts with increased counts included categories R (general function prediction only), M (cell wall/membrane biogenesis), O (posttranslational modification, protein turnover, chaperones), and $\mathrm{V}$ (defense mechanisms) as well as unassigned genes not in COGs. More specifically, rpfF (DSF-synthase, LFTS_00514) transcript counts were increased in response to exposure to AHLs (Fig. 9 and Supplemental Table S2). In general, the transcriptomes indicated low transcript counts of the sensor Hpt domain containing protein encoding gene (LFTS_00515) while the average transcript counts of the adjacent $r p f C$ sensor kinase (LFTS_0516) were one order of magnitude higher. Both genes had slightly increased transcripts in cells exposed to DSF/BDSF and AHLs (LFTS_00515; DSF: LFC $=0.53$ and $p=6 \times 10^{-3}$, AHL: LFC $=0.69$ and $p=10^{-3}$; LFTS_0516; DSF: LFC $=0.38$ and $p=4 \times 10^{-4}$, AHL: LFC $=0.54$ and $\left.p 2 \times 10^{-9}\right)$. Likewise, transcripts coding for the cognate response regulator $r p f G$ (LFTS_00517) were increased in cells exposed to DSF/BDSF or AHLs (LFTS_00517; DSF: LFC $=0.29$ and $p=4 \times 10^{-4}$, AHL: LFC $=0.87$ and $p=3 \times 10^{-34}$ ). Furthermore, AHL-treatment caused increased transcript counts for the same multidrug efflux systems as for DSF/BDSF treatment plus one additional multidrug efflux system (LFTS_00325 - _00327,_00329). However, even though these defense systems were triggered, toxic effects of AHLs or inhibition of iron oxidation as compared to treatment with comparable concentrations of DSF or BDSF (Figs. 6 and 7) were not observed. The active growth of Leptospirillum cells in the presence of AHLs was also reflected by several genes with increased transcript counts that were associated with functions such as carbon and nitrogen fixation, respiration, central carbon metabolism, ammonium uptake, biosynthesis of amino acids, iron-sulfur-clusters, cytochromes, nucleotides, vitamins, lipopolysaccharides, and cell walls/membranes. Finally, a further parallel finding after treatment with the AHL mixture and DSF/BDSF was lower transcript counts for flagella biosynthesis and chemotaxis related genes (Supplemental Table S2).

\section{Discussion}

Biofilm communities are crucial in biomining since they regenerate iron(III)-ions that oxidize the metal sulfide directly on the mineral surface. However, too thick biofilms may passivate the mineral surface due to limitation of rate determining iron-ion and ISC transport processes. Consequently, biofilm dispersal is important for the biologically catalyzed metal sulfide oxidation e.g. in heap bioleaching processes. This is by ensuring that mono-layer biofilms are dominant ${ }^{11}$ to support contact of metal sulfide surfaces with the leaching solution and facilitating colonization of downstream mineral surfaces. DSF-signaling has been widely reported as a biofilm dispersal factor in a broad range of species ${ }^{32,34}$. Recently we demonstrated this effect in some bioleaching bacteria, observing a decrease in mineral-attached Acidithiobacillus caldus, L. ferriphilum, and S. thermosulfidooxidans populations on mineral particles after DSF addition ${ }^{15}$. It was also proposed that biofilm dispersal upon external addition of DSF family signal compounds is an active biological function of DSF signaling in leptospirilli.

The other major effect of DSF is the inhibition of biological iron oxidation (Figs. 6, 7, 8), which causes inhibition of bioleaching and a concentration dependent toxic effect of DSF/BDSF was reflected in the transcriptomic analysis. Micromolar DSF/BDSF concentrations are unlikely to occur in leptospirilli containing habitats and the biogenic concentrations of DSF in batch pyrite cultures (Fig. 4) were one order of magnitude below the lowest inhibitory levels that were tested in the iron(II) oxidation assays. However, we suggest this phenomenon will be at least partially biologically relevant in close proximity to mineral attached Leptospirillum cells as elevated concentrations likely occur via fatty acid accumulation in cell membranes and the EPS layer. Pyrite-grown cells were shown to be adapted to the presence of biogenic DSF family compounds (Fig. 6), while unadapted 
intruding cells will be inhibited, preventing access to the energy source. Consequently, the previously described mutual inhibitory interaction in pyrite cultures inoculated with L. ferrooxidans and Acidiferrobacter sp. SPIII/ $3^{20}$ was likely a result of the high sensitivity of Acidiferrobacter sp. SPIII/3 to DSF/BDSF that inhibited growth or even caused cell lysis, while its AHL production or exudates potentially inhibited L. ferrooxidans. A second example of an interspecies interaction likely mediated via DSF was the decreased leaching performance by $S$. thermosulfidooxidans cells added to pyrite cultures pre-colonized by L. ferriphilum compared to simultaneous inoculation with L. ferriphilum and S. thermosulfidooxidans ${ }^{42}$. This was potentially due to DSF release by L. ferriphilum mineral-oxidizing micro-colonies prior to the addition of $S$. thermosulfidooxidans. DSF then specifically inhibits iron(II) oxidation in intruding $S$. thermosulfidooxidans cells. The effect might also contribute to the preference for ISC oxidation by $S$. thermosulfidooxidans when in co-culture with L. ferriphilum ${ }^{43}$, while in batch cultivation systems exudates from $S$. thermosulfidooxidans likely inhibit L. ferriphilum ${ }^{\mathrm{T}}$. In this work, it was also shown that extracts from pyrite grown cultures of $L$. ferriphilum ${ }^{\mathrm{T}}$ were able to inhibit Acidiferrobacter sp. SPIII/3 and L. ferrooxidans iron oxidation. Previously it has been shown that L. ferriphilum ${ }^{\mathrm{T}}$ extracts widely inhibit iron oxidation of the Gram-positive S. thermosulfidooxidans ${ }^{\mathrm{T}}$ and Acidimicrobium ferrooxidans, as well as in several acidithiobacilli, such as At. ferrooxidans, At. ferrivorans and At. ferriphilus. Interestingly, the addition of L. ferriphillum ${ }^{\mathrm{T}}$ extracts showed no inhibitory effects against cultures of $S$. thermosulfidooxidans, At. caldus, and At. thiooxidans when grown using elemental sulfur as the sole energy source ${ }^{44}$. We propose that the production of DSF by actively mineral-oxidizing cells is a sound strategy to keep the mineral energy source primarily accessible to DSF-producing leptospirilli. Therefore, and taking into account that pyrite grown L. ferriphilum ${ }^{\mathrm{T}}$ cells were less sensitive regarding inhibition of iron oxidation by DSF, it is likely that at the micro-colony scale the niche defense hypothesis explains the biological advantage of DSF production in leptospirilli. In this context, the production of DSF could also contribute to modulate substrate oxidation of competing neighbor species by switching-off their iron oxidation pathways, without interfering on their capacities to oxidize ISCs. In addition, that DSF-family signal compounds are biofilm dispersal factors is also in agreement with the observation that in a filtered pyrite leachate from $L$. ferriphilum, S. thermosulfidooxidans tend to oxidize ISCs instead of ferrous iron at decreased numbers of mineral-attached cells ${ }^{42}$. Bioleaching communities are complex, and several heterotrophic microorganisms are always present. These exert complex nutritional interactions with iron/sulfur oxidizing chemolithotrophs by feeding organic carbon and substrates that can be toxic for the chemolithotrophs ${ }^{50}$. In the future, it will be interesting to determine if there are effects related to the presence of DSF in mixed cultures containing Leptospirillum, Acidithiobacillus as well as heterotrophic species such as Acidiphilium spp.

DSF and BDSF inhibited iron oxidation to varying degrees in all tested iron-oxidizers (Fig. 7) raising the question of the inhibitory mechanism. Organic acids are protonated at $\mathrm{pH}$ values below their specific $\mathrm{pK}_{\mathrm{a}}$ value and hence, DSF-family compounds are protonated in the experimental conditions and act as uncouplers by entering cells and releasing a proton within the near $\mathrm{pH}$ neutral periplasm. This readily explained elevated RNA transcript counts for multidrug efflux systems after DSF family compound addition. However, At. ferrooxidans, former Thiobacillus ferrooxidans strains have been shown to grow in the presence of small organic acids, such as acetic or citric acid, at concentrations three or four orders of magnitude higher than the inhibitory or lethal levels for DSF family compounds ${ }^{45-48}$. In addition, Aston et al., 2009 reported the toxic effects of several organic acids to At. caldus, strain BC13. This included oxaloacetate, pyruvate, acetate, malate, succinate, fumarate, oxaloacetate and 2-ketoglutarate. All of them exhibited toxicity between 1-5 mM, while oxaloacetate was toxic at $0.25 \mathrm{mM}^{49}$. Nancucheo \& Johnson, in 2010, reported toxicity of glycolic acid against L. ferriphilum ${ }^{\mathrm{T}}$ and L. ferrooxidans ${ }^{\mathrm{T}}$. The maximum concentration of glycolic acid that permitted growth was close to the mM range, with 0.5 and $0.1 \mathrm{mM}$, respectively ${ }^{50}$. Interestingly, the acyl-chain length of fatty acid correlates with enhanced toxicity ${ }^{51}$ and long-chain fatty acids are known for their detrimental effect on the performance of anaerobic sewage sludge digestion processes and their inhibitory effect on methanogenic archaea ${ }^{52,53}$. Furthermore, unsaturated fatty acids are known antimicrobials that cause membrane disruption in Gram-positive bacteria ${ }^{54}$. Therefore, the observed DSF transcriptional effect would not only involve QS signaling via DSF perception and response regulator components, but would also potentially include an acid stress response upon direct uptake of DSF molecules. This was supported by the transcriptional analyses, which showed $r p f F$ transcript counts were not significantly increased upon DSF/BDSF treatment but were increased after AHL addition. Also, the DSF/BDSF effect could not be related to its sensing and response regulation via RpfC and RpfG proteins. Interestingly, flrB transcript levels were decreased in L. ferriphilum after both DSF/BDSF and AHL mixture treatments. In Vibrio alginolyticus it has been reported that $f \operatorname{lr}$ genes (including $f t r A, f l r B$, and $f l r C$ ) influence bacterial adhesion, motility, biofilm formation, and EPS production and some strains cultured under $\mathrm{Cu}^{2+}, \mathrm{Pb}^{2+}, \mathrm{Hg}^{2+}$ or low-pH conditions showed a significant down-regulation of these genes, leading to deficiencies in adhesion, motility, flagellar assembly, biofilm formation, and EPS production ${ }^{55}$. In agreement with these observations, DSF and AHL addition produced a decrease in transcript counts of $L$. ferriphilum flagellar related genes, flagellar basal-body rod proteins $(\mathrm{flg})$, flagellar biosynthetic protein $(\mathrm{flh})$, and other flagellar genes $(\mathrm{fli})$. As DSF was added to planktonic cultures, the transcript decay observed for flagellar genes and motility functions suggested that cells switched to a sessile state. In contrast, natural DSF signaling in X. campestris pv. campestris and Xanthomonas axonopodis pv. citri increases the expression of genes involved in flagellum biosynthesis ${ }^{56,57}$. This difference may be due to the different experimental approaches along with the effects of gene deletions that could be more complex or unexpectedly influence other regulatory pathways, compared to external addition of signalling molecules. For example, in Cronobacter turicensis it has been reported that the flagellar regulon-associated gene flhE is unaltered in the $r p f F / R$ mutants, but it is significantly upregulated in complemented mutants carrying additional copies of these genes $^{58}$. We also highlight that the organization of the rpfFCG gene cluster as a putative uni-directional operon structure in both Leptospirillum species (Fig. 1) differs from the convergent organization of $r p f F$ and $r p f C G$ described for Xanthomonas spp., Stenotrophomonas maltophila and Xylella fastidiosa ${ }^{32}$. Consequently, regulatory 


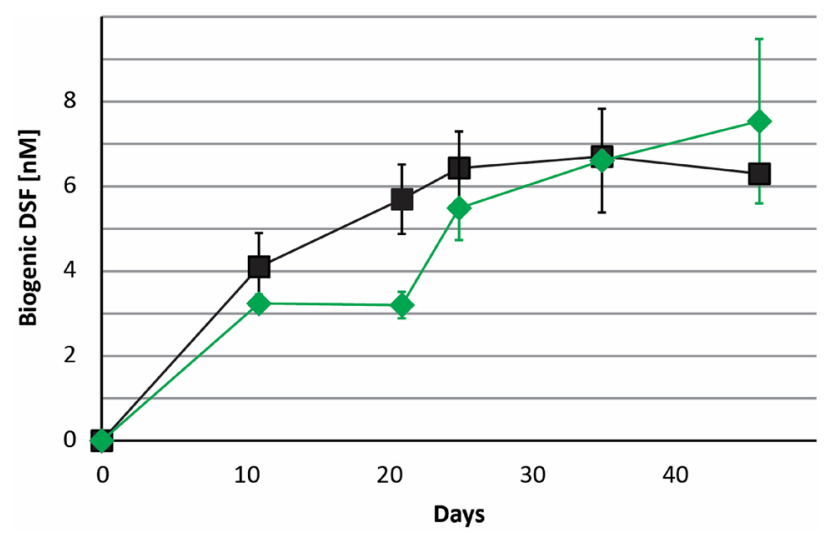

Figure 4. Development of DSF concentrations in Leptospirillum spp. culture supernatants. Concentration of biogenic DSF in cultures of L. ferrooxidans ${ }^{\mathrm{T}}$ (black boxes) and L. ferriphilum ${ }^{\mathrm{T}}$ (green diamonds) as calculated using GC-MS chromatogram peak areas. Data are averages \pm SD from triplicate experiments $(n=3)$ using normalized peak areas (internal standard) converted to concentration levels using an external calibration.

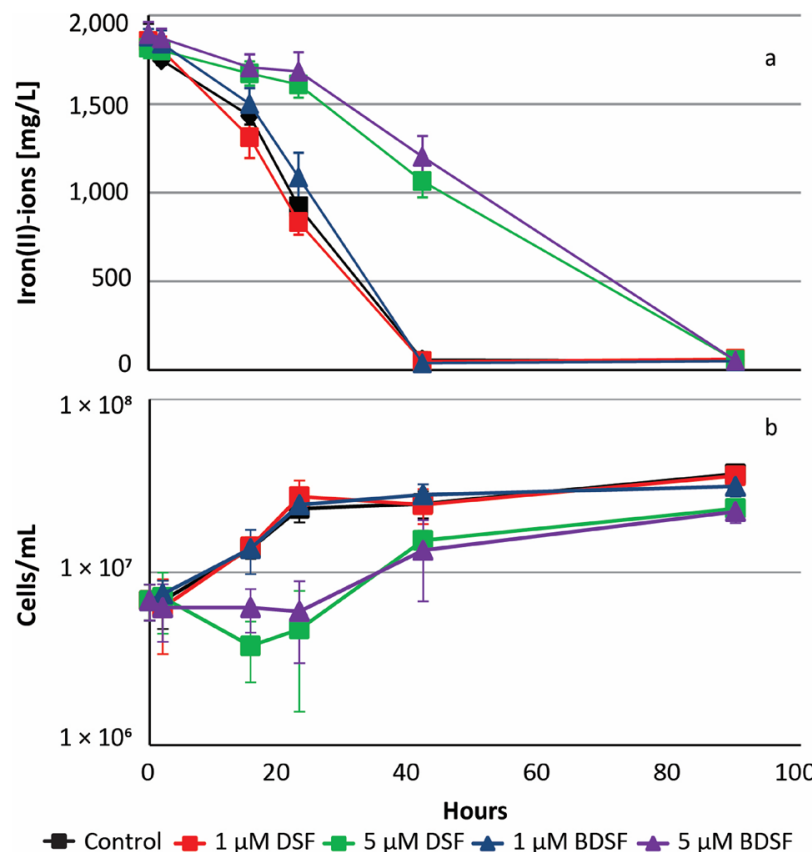

Figure 5. DSF or BDSF inhibit biological iron oxidation and cell growth. Cultures were inoculated with $10^{7}$ cells/mL iron(II)-grown cells of L. ferriphilum ${ }^{\mathrm{T}}$. DSF or BDSF was added at 1 or $5 \mu \mathrm{M} 16 \mathrm{~h}$ before $32 \mathrm{mM}$ iron(II)-ions were added. Cells are inhibited in iron(II) oxidation (a) and growth (b) in presence of $5 \mu \mathrm{M}$ DSF ((Z)-11-methyl-2-dodecenoic acid, green boxes) or $5 \mu \mathrm{M}$ BDSF ((Z)-2-dodecenoic acid, purple triangles).

mechanisms of this gene cluster may differ in leptospirilli, and further experiments are needed to evaluate DSF effects on mixed biofilm cultures containing L. ferriphilum ${ }^{T}$.

As mentioned above, the c-di-GMP second messenger is associated with the control of several phenotypes including EPS production and biofilm formation ${ }^{27}$. In particular, QS is related to c-di-GMP metabolism in some Gram-negative acidophiles and potentially represents an important mechanism regulating both process ${ }^{20,24,26,30,31}$. The L. ferriphilum ${ }^{\mathrm{T}}$ genome contains ten genes annotated as encoding putative DGCs, 13 genes encoding proteins containing both DGC and PDE specific GGDEF and EAL domains, and two c-di-GMP-specific PDE ${ }^{43}$. Among these genes, eight are RpfR homologous, which could have the potential to perceive and regulate DSF effects, as described in Burkholderia and other $r p f R$ containing species (Supplemental Fig. S1). Furthermore, four additional genes encoding HD/HDc domain-containing proteins and three genes encoding PilZ domain-containing c-di-GMP effector proteins were found. The latter genes were annotated as being related to functions such as cellulose and extracellular polysaccharide biosynthesis and export. This suggested that c-di-GMP metabolism also had an important function in the regulation of EPS production and biofilm formation in L. ferriphilum ${ }^{\mathrm{T}}$. Interestingly, the dos C gene (LFTS_01845) encoding a diguanylate cyclase (GGDEF) domain-containing protein 


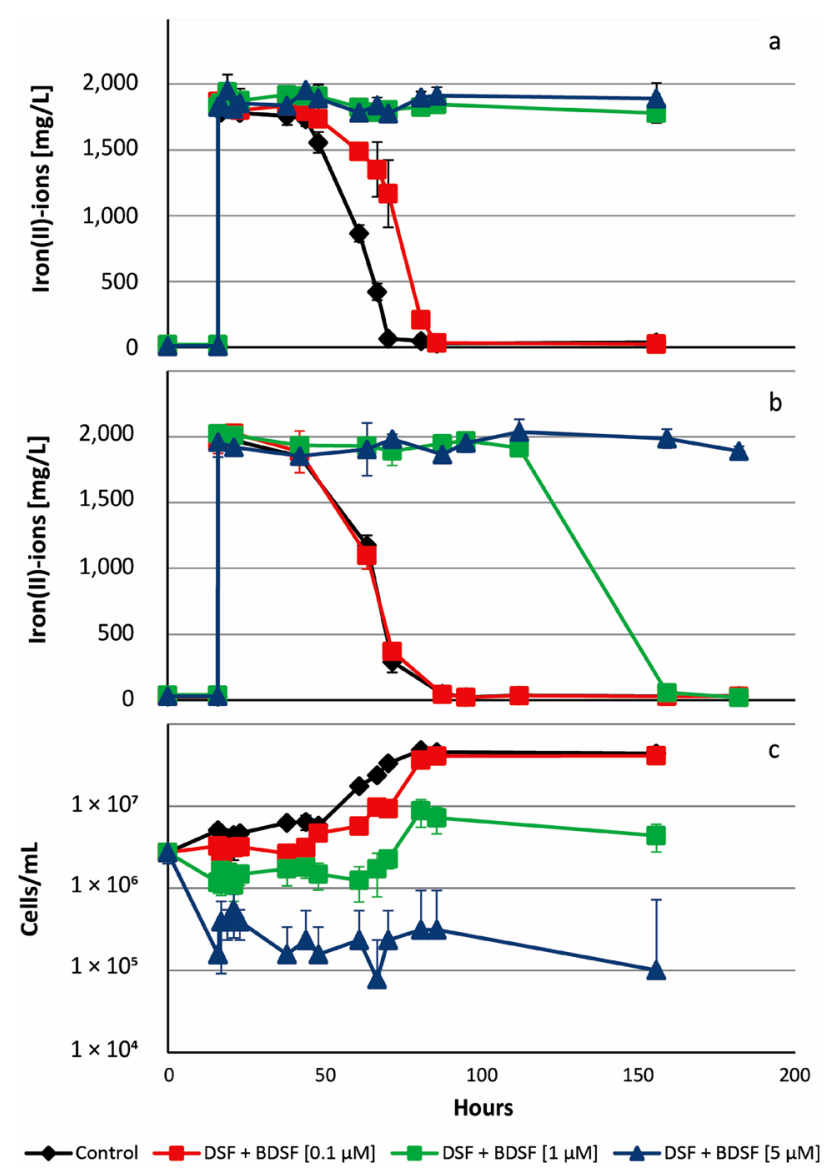

Figure 6. Iron-grown cells of L. ferriphilum ${ }^{\mathrm{T}}$ are more sensitive to inhibition by DSF molecules than pyrite grown cells. Cultures were inoculated with $4 \times 10^{6}$ cells $/ \mathrm{mL}$ cells of $L$. ferriphilum ${ }^{\mathrm{T}}$ and exposed to $0.1,1$, and $5 \mu \mathrm{M}$ DSF ((Z)-11-methyl-2-dodecenoic acid) and BDSF ((Z)-2-dodecenoic acid) for $16 \mathrm{~h}$ before $32 \mathrm{mM}$ iron(II)-ions were added. Iron(II)-grown (a) and pyrite-grown cells (b) were differentially inhibited in iron(II) oxidation. Growth in presence of increasing concentrations DSF/BDSF is strongly effected as shown for iron(II)grown cells $(\mathbf{c})$.

presented significantly increased transcripts levels in both DSF- and AHL-treated cells. DosC (direct oxygen sensing cyclase) is a globin-coupled heme-based oxygen sensor protein, displaying DGC activity in response to oxygen availability and regulating biofilm formation in an oxygen-dependent manner in Escherichia coli ${ }^{59}$. Some phenotypes related to its regulation include the production of poly-N-acetylglucosamine (PNAG) and cellulose in strains able to produce them and it leads to increased biofilm formation and decreased swimming in some motile strains ${ }^{60}$. The increased transcript counts of DosC also supported a DSF induced transition to sessile lifestyle in L. ferriphilum ${ }^{\mathrm{T}}$.

The active growth of Leptospirillum cells in the presence of AHLs was in contrast to inhibition in iron oxidation and cell growth of L. ferriphilum after DSF and BDSF addition (Fig. 6). The detrimental effect of DSF/BDSF was reflected by decreased transcript counts for genes associated with basic cellular functions such as carbohydrate transport and metabolism, amino acid transport and metabolism, energy production and conversion, cell wall membrane biogenesis, inorganic ion transport and metabolism, and cell motility. Gene ndhF (LFTS_01821) that encodes $\mathrm{NAD}(\mathrm{P}) \mathrm{H}$-quinone oxidoreductase subunit 5 (of NDH-1) had one of the most significant decreases in transcript counts. The NDH-1 complex shuttles electrons from NAD $(\mathrm{P}) \mathrm{H}$, via FMN and iron-sulfur (Fe-S) centers, to quinones in the respiratory chain ${ }^{61}$. The change in transcripts levels of this gene potentially reflected a lower energy production capacity, in agreement with inhibition in cell growth. In addition, several genes related to cell wall membrane biogenesis presented lower transcript counts including glycosyltransferase genes $w c f N$ (LFTS_00540) and $w b d M$ (LFTS_00541), $g f c E$ gene (LFTS_00550) that encodes polysaccharide export outer membrane protein and wcaJ (LFTS_00551) that codes for a polyprenyl glycosylphosphotransferase. Gene atoS (LFTS_01830) also showed a decrease in transcript counts that codes for a membrane-associated kinase in the AtoS/AtoC two-component system regulating e.g. inhibition of ornithine decarboxylase (ODC), a key enzyme in polyamine synthesis ${ }^{62}$. Polyamines are implicated in many physiological functions such as DNA replication and repair, transcription, protein synthesis, and post-translational protein modifications and its inhibition retards or stops cell growth ${ }^{63}$. In addition, AtoS/AtoC also regulates chemotaxis and flagellar regulons ${ }^{63}$. While a decrease in $a t o S$ transcripts would involve alterations in several cellular processes, no changes in transcript levels were 


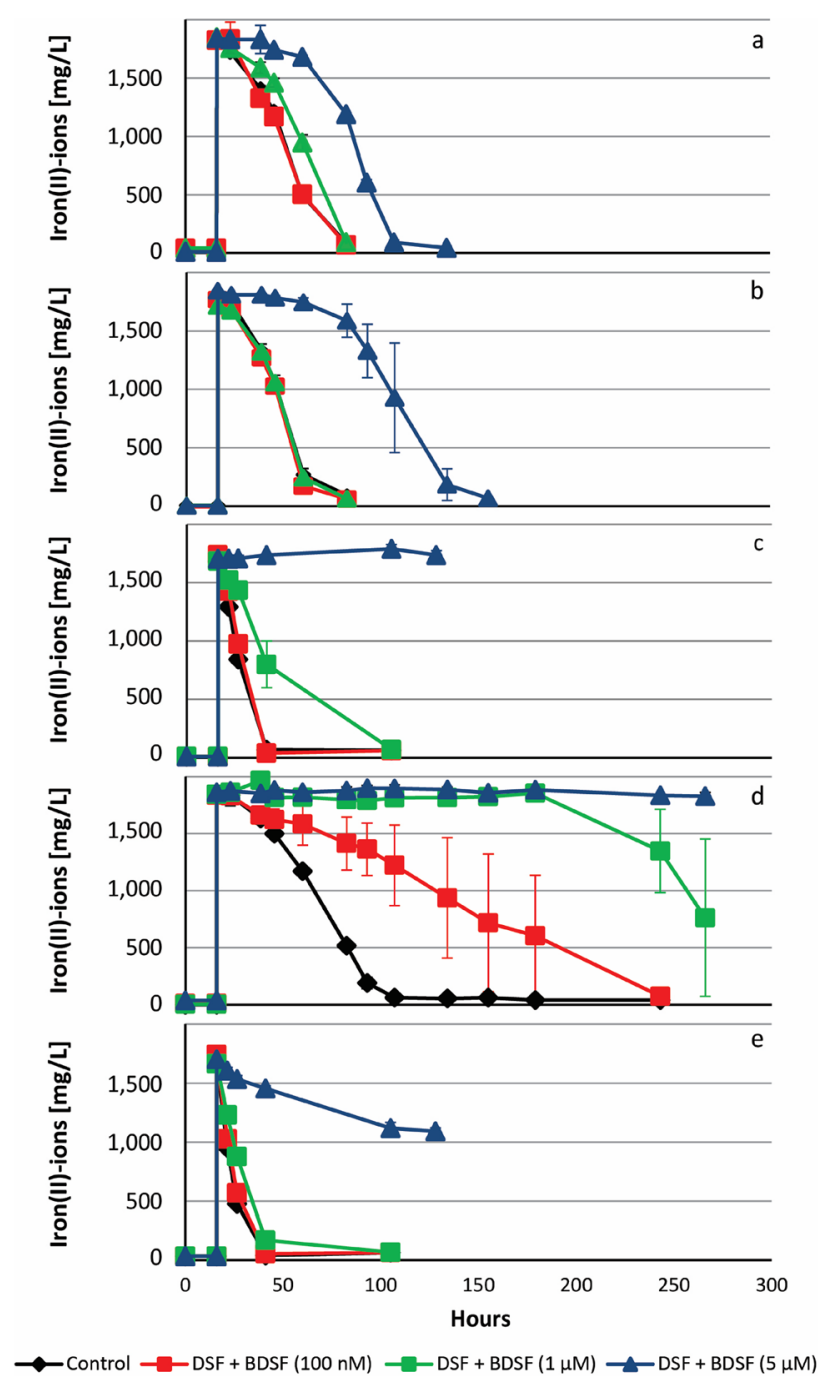

Figure 7. DSF and BDSF inhibit biological iron oxidation in various acidophilic bacteria. Cultures were inoculated with $10^{7}$ cells/mL iron(II)-grown cells of At. ferrooxidans ATCC 53,993 (a), At. ferridurans ${ }^{\mathrm{T}}$ (b), $L$. ferrooxidans $^{\mathrm{T}}$ (c), Acidiferrobacter sp. SPIII/3 DSM 27,195 (d), and S. thermosulfidooxidans ${ }^{\mathrm{T}}(\mathbf{e})$ and exposed to DSF ((Z)-11-methyl-2-dodecenoic acid) and BDSF ((Z)-2-dodecenoic acid) for $16 \mathrm{~h}$ before $32 \mathrm{mM}$ iron(II)-ions were added.

detected in other ato operon genes or ato $C$ and this variation could not be correlated with polyamine biosynthesis or fatty acid degradation. Interestingly, for many of the proteins regulated by the DSF/Rpf system in X. campestris, their alteration in abundance was not associated with changes at transcript levels, suggesting that both posttranscriptional regulation and post-translational turnover may occur. Therefore, to confirm any DSF/BSDF or AHL effect over cellular process that may lead to inhibition in iron oxidation and/or cell growth of L. ferriphilum and other acidophiles, it is important to complement future transcriptomic studies with quantitative proteomics.

Finally, we conclude that the data supported the hypothesis that Leptospirillum spp. DSF production may be part of a niche defense strategy of established mineral-attached microcolonies. Furthermore, we propose that the finding of efficient inhibition of biological iron oxidation by DSF family compounds has potential for a possible application to prevent unwanted bioleaching.

\section{Material and methods}

Bacteria and growth conditions. The species used in the study were the Gram-negative iron- and sulfuroxidizing bacteria At. ferrooxidans ATCC 53993, At. ferridurans ATCC $33020^{\mathrm{T}}$, and Acidiferrobacter sp. SPIII/3 DSM 27195; Gram-negative iron-oxidizing bacteria L. ferriphilum DSM $14647^{\mathrm{T}}$ and L. ferrooxidans DSM $2705^{\mathrm{T}}$; and the Gram-positive iron- and sulfur-oxidizing bacterium S. thermosulfidooxidans DSM 9293 ${ }^{\mathrm{T}}$. Bacterial cells were grown in Mackintosh basal salt solution (Mac medium) pH $2.0^{65}$ with $72 \mathrm{mM}$ iron(II) supplied as $\mathrm{FeSO}_{4} \cdot 7 \mathrm{H}_{2} \mathrm{O}$. For $\mathrm{S}$. thermosulfidooxidans ${ }^{\mathrm{T}}$, the medium was amended with $0.02 \%$ (wt/vol) yeast extract. Mac medium, ferrous sulfate $\left(\mathrm{FeSO}_{4} \cdot 7 \mathrm{H}_{2} \mathrm{O}, 200 \mathrm{~g} / \mathrm{L}, \mathrm{pH} 1.2\right)$, and yeast extract were autoclaved separately at $121^{\circ} \mathrm{C}$ 
a

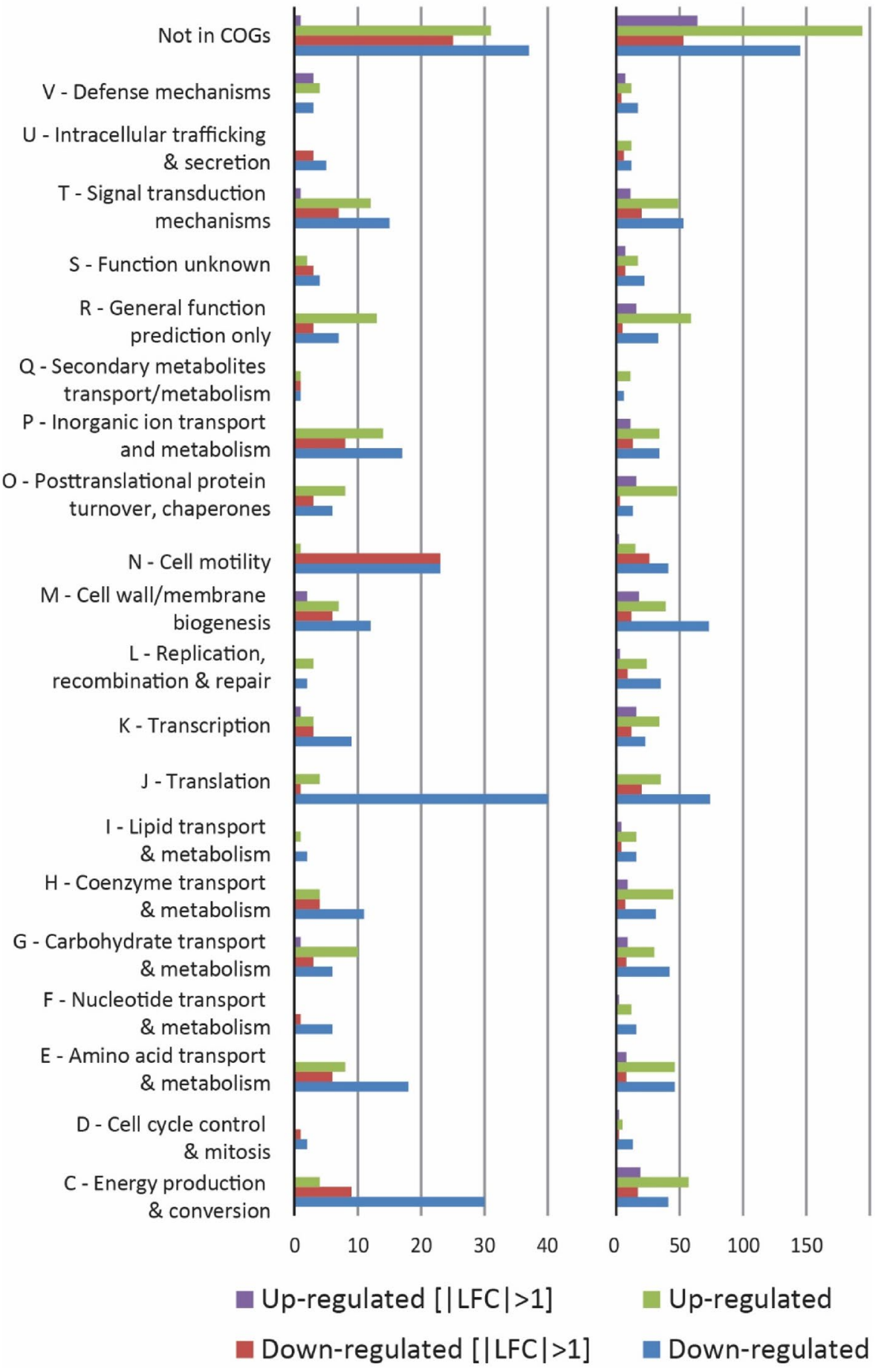

Figure 8. Clusters of orthologous groups (COGs) analysis of transcriptional changes in cells of L. ferriphilum DSM $14647^{\mathrm{T}}$ after exposure to DSF/BDSF (a) and AHLs (b). Numbers COG-assigned differentially expressed genes with $p a d j<0.005$ are shown as green and blue bars for higher and fewer RNA transcripts, respectively (393 and 1450 genes in total for DSF/BDSF and AHLs, respectively). Purple and red bars indicate the fraction of RNA transcripts with $|\mathrm{LFC}|>1$ (100 and 419 genes for DSF/BDSF and AHLs, respectively). 

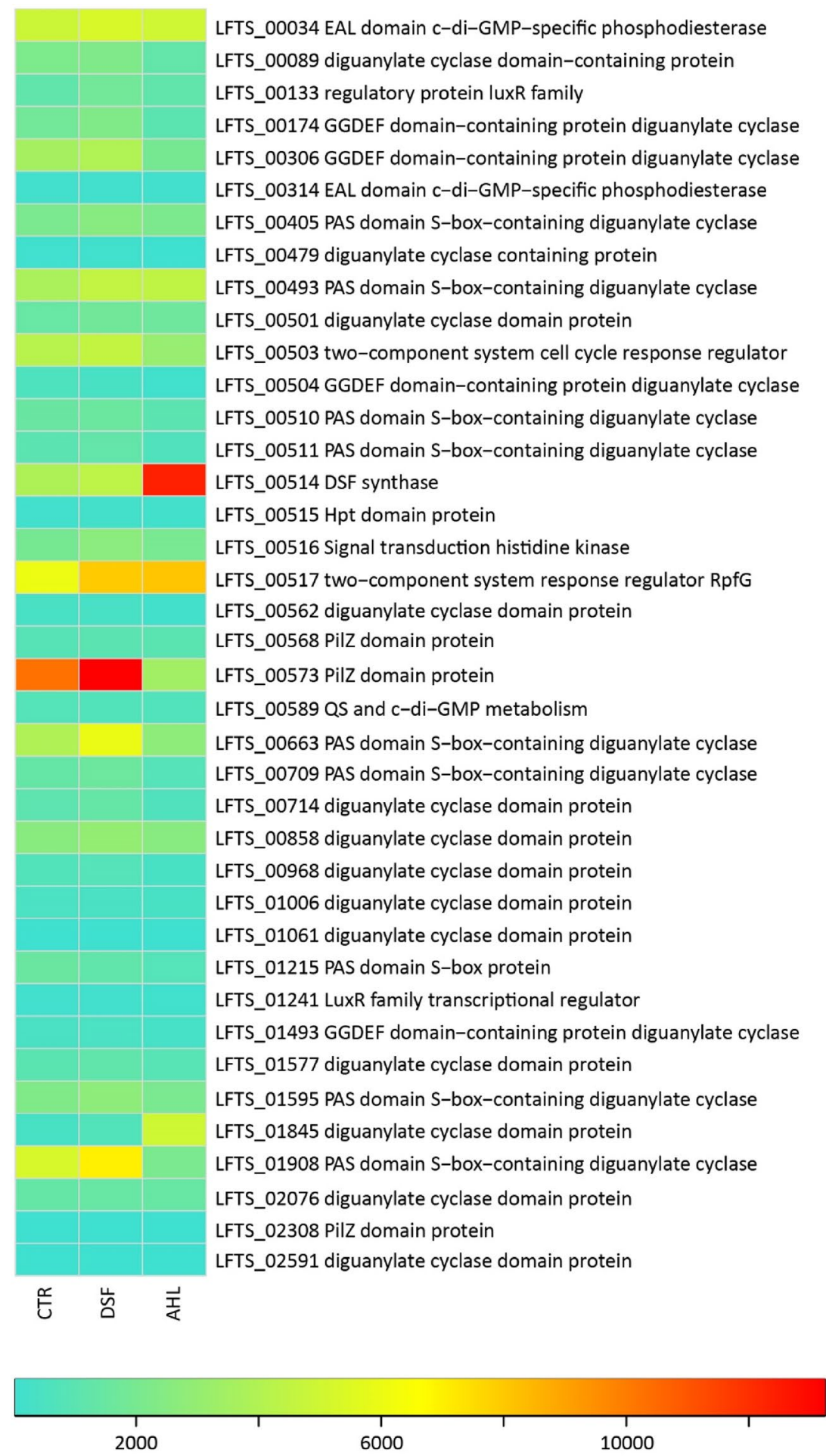

Figure 9. Heatmap of averaged counts of transcripts of QS and c-di-GMP metabolism genes. Color-coded averaged counts of transcripts indicate low ( 0 ; turquoise), medium (6500; yellow) and high (13,000; red) counts of gene transcripts in RNA samples from cells exposed to DSF molecules (DSF), N-acyl-homoserine-lactones (AHL) or control cells (CTR). 
for $20 \mathrm{~min}$. Cultures were incubated under constant shaking at $140 \mathrm{rpm}$. The Acidithiobacillus strains as well as Acidiferrobacter sp. SPIII/3 DSM 27195 and L. ferrooxidans

${ }^{\mathrm{T}}$ were grown at $30^{\circ} \mathrm{C}$, L. ferriphilum ${ }^{\mathrm{T}}$ at $37^{\circ} \mathrm{C}$, and S. thermosulfidooxidans ${ }^{\mathrm{T}}$ at $45^{\circ} \mathrm{C}$. Cells were also cultivated using pyrite as energy source. Cultures of L. ferriphilum ${ }^{\mathrm{T}}$ and L. ferrooxidans ${ }^{\mathrm{T}}$ for bioleaching experiments and extraction of signal compounds were prepared as described for iron-cultures regarding agitation and growth temperature using $100 \mathrm{~mL}$ Mac medium pH 2.0 with $2 \%$ (wt/vol) pyrite grains $(50-100 \mu \mathrm{m})$ as sole substrate. Cultures were prepared in triplicate and inoculated with $10^{7}$ cells $/ \mathrm{mL}$ per species. Growth curves were followed by cell counting under light microscopy as previously described ${ }^{14,15,20}$.

Pyrite preparation. Pyrite concentrate with a grain size of 50-100 $\mu \mathrm{m}$ was used (Baia Mare, Romania) that was treated as previously described ${ }^{66}$. Briefly, 100 g pyrite grains were boiled in $200 \mathrm{~mL} 6 \mathrm{M} \mathrm{HCl}$ for 30 min and then washed with deionized water until the $\mathrm{pH}$ was neutral. Afterward, grains were stirred twice in $100 \mathrm{~mL}$ acetone for $30 \mathrm{~min}$ to remove soluble sulfur compounds by discarding the solvent after the treatment. After evaporation of residual acetone, the washed pyrite was stored in a nitrogen atmosphere, and sterilized for $12 \mathrm{~h}$ at $125^{\circ} \mathrm{C}$.

Iron oxidation activity tests. Early stationary phase iron(II)- and pyrite-grown cells were harvested at $7000 \mathrm{~g}$ for $10 \mathrm{~min}$ at room temperature, washed, and subsequently re-suspended in Mac medium $\mathrm{pH}$ 2.0. In case of pyrite-grown cells, a low speed centrifugation step $(500 \mathrm{~g}, 1 \mathrm{~min}$ ) was used to remove small pyrite particles. Afterwards, the cells were used for inoculation of triplicate $50 \mathrm{~mL}$ assays in $100 \mathrm{~mL}$ Erlenmeyer flasks with Mac medium at pH 2.0 amended with DSF ((Z)-11-methyl-2-dodecenoic acid, CAS 677354-23-3; Sigma) and BDSF ((Z)-2-dodecenoic acid, CAS 55928-65-9; Sigma). The cells were exposed to the signal molecules for $16 \mathrm{~h}$ without addition of an energy source and incubated with agitation at the specified growth temperature of the respective bacterial species. Afterwards, $32 \mathrm{mM}$ iron(II)-ions were added and the assays were further incubated while quantifying iron(II)-ions using the phenanthroline method $^{64}$ and planktonic cells using a phase contrast microscope and a Thoma chamber. The inoculum size was set at $10^{7}$ cells $/ \mathrm{mL}$ for all experiments with combined DSF and BDSF at $0.1,1$, and $5 \mu \mathrm{M}$ per compound along with a smaller inoculum of $4 \times 10^{6}$ cells $/ \mathrm{mL} \mathrm{L.} \mathrm{ferriphilum}{ }^{\mathrm{T}}$ for exposure to individual DSF and BDSF compounds at 1 and $5 \mu \mathrm{M}$. Control assays were prepared by addition of an equal volume of dimethyl sulfoxide (DMSO) that was used as solvent for the DSF and BDSF stock solutions.

For cultures treated with $L$. ferriphilum ${ }^{\mathrm{T}}$ extracts $(0.2 \% \mathrm{vol} / \mathrm{vol})$, early stationary phase iron(II)-grown cells were harvested at $7000 \mathrm{~g}$ for $10 \mathrm{~min}$ at room temperature, washed, and subsequently re-suspended in Mac medium $\mathrm{pH}$ 1.6. The cells were used for inoculation of $20 \mathrm{~mL}$ assays in $100 \mathrm{~mL}$ Erlenmeyer flasks with Mac medium at pH 1.6 and $72 \mathrm{mM}$ iron(II)-ions for L. ferrooxidans ${ }^{\mathrm{T}}$ and Acidiferrobacter sp. SPIII/3 cultures or $100 \mathrm{mM}$ iron(II)-ions for L. ferriphilum ${ }^{\mathrm{T}}$. Control assays were prepared by addition of an equal volume of hexane or ethanol that were used as solvent for the L. ferriphilum ${ }^{\mathrm{T}}$ extracts. Flasks were incubated with agitation at $120 \mathrm{rpm}$ and periodically sampled in order to follow iron(II) oxidation and planktonic cell growth as mentioned above.

Extraction of signaling compounds from batch pyrite cultures of Leptospirillum spp. Axenic pyrite cultures of $L$. ferriphilum ${ }^{\mathrm{T}}$ and $L$. ferrooxidans ${ }^{\mathrm{T}}$ were prepared in triplicate for each sampling time point and sacrificed for metabolite extraction from the liquid cell culture and the colonized pyrite by addition of $100 \mathrm{~mL}$ dichloromethane (p.a.) and stirring for $30 \mathrm{~min}$ at room temperature at $500 \mathrm{rpm}$. Erlenmeyer flasks, other glass materials used for handling the extracts, and magnetic stirring bars were cleaned in a laboratory dishwasher and subsequently rinsed with $6 \mathrm{M} \mathrm{HCl}$, de-ionized water, and twice with dichloromethane to exclude contamination of metabolite extracts. The organic phase was recovered using a separation funnel, concentrated by rota-evaporation at $750 \mathrm{mbar}$ and $35^{\circ} \mathrm{C}$ to a volume of $2-4 \mathrm{~mL}$, and transferred to brown glass vials with Teflon sealed screw caps using a glass Pasteur pipette and stored at $-20^{\circ} \mathrm{C}$. Residual dichloromethane was evaporated prior to use of the extracts using a pure nitrogen stream before directly re-dissolving in $500 \mu \mathrm{L}$ ethanol (p.a.). Solvents and chemicals were of analytical grade (p.a.) and supplied by VWR.

Bioassay for BDSF/DSF. The bioassay was performed as previously described ${ }^{41}$. Briefly, B. cenocepacia H111-rpfF ${ }_{B c}$ (pan-L15) was grown in Luria Bertani (LB) medium with chloramphenicol $(80 \mu \mathrm{g} / \mathrm{mL}$ ) and kanamycin $(100 \mu \mathrm{g} / \mathrm{mL})$ at $30^{\circ} \mathrm{C}$. A fresh overnight culture at an OD 600 of 1.8-2.0 was diluted 1:1 with LB medium from which, $200 \mu \mathrm{L}$ was added to 96 -well plates (transparent, Brandt ${ }^{41}$. Before addition of the biosensor culture, synthetic standard compounds or extracts from acidophile bacterial cultures were added to the plate in triplicate. Synthetic BDSF, DSF, and various AHL standards dissolved in DMSO were added to individual wells in the 96-well plate (DMSO was used for the control). Extracts from Leptospirillum spp. pyrite cultures $(300 \mu \mathrm{L})$ were re-dissolved in ethanol and added to individual wells in the plate. The solvent was evaporated at room temperature in a laminar flow chamber before addition of the biosensor culture. The plates were incubated for $20 \mathrm{~h}$ at $30^{\circ} \mathrm{C}$. Afterwards, $2 \mu \mathrm{L}$ decanal (Sigma) was added to each well to detect luciferase activity of the biosensor using a luminometer. Luminescence levels in arbitrary units (AU) were recorded using a plate reader (FLUOstar Omega $^{\text {tw }}$, BMG Labtech ${ }^{\circ}$.

Identification of DSF in culture extracts using GC-MS. A Thermo Scientific Trace 1310 GC and ISQ Single Quadrupole Mass Detector (ISQ-MS) operated in auto-sampler mode with helium as carrier gas and a non-polar capillary GC column was used (DB-5MS, $30 \mathrm{~m} \times 0.25 \mu \mathrm{m}$, ID $0.25 \mathrm{~mm}$, J\&W Scientific, USA). Mass spectra were obtained by electron impact ionization $(70 \mathrm{eV})$, the front inlet temperature was $250^{\circ} \mathrm{C}$, and injection was done in split less mode. The mass transfer line temperature was $250^{\circ} \mathrm{C}$ and the temperature program 
was: initial temperature $50^{\circ} \mathrm{C}$ (hold for $2 \mathrm{~min}$ ) and raised to $260^{\circ} \mathrm{C}$ with increasing rate of $15^{\circ} \mathrm{C} / \mathrm{min}$ and final temperature was hold for $5 \mathrm{~min}$ (total run time $21 \mathrm{~min}$ ). DSF and BDSF were used as standards.

RNA extraction, rRNA depletion, library preparation, and sequencing. Planktonic cells from iron(II) cultures of $L$. ferriphilum ${ }^{\mathrm{T}}$ were grown to early stationary phase in Mac medium $\left(\mathrm{pH} 1.8,37^{\circ} \mathrm{C}\right)$ with $72 \mathrm{mM}$ iron(II)-ions and harvested by centrifugation $(7,000 \mathrm{~g}, 10 \mathrm{~min})$. The cultures were inoculated at $10^{8}$ cells/ $\mathrm{mL}$ in $100 \mathrm{~mL}$ Erlenmeyer flasks with $50 \mathrm{~mL}$ Mac medium ( $\mathrm{pH}$ 1.8). Three cultivation conditions were compared by transcriptomic analyses. Namely, cultures were amended with combined (1) DSF and BDSF ( $2 \mu \mathrm{M}$ each), (2) a mixture of AHLs namely N-dodecanoyl-DL-homoserine lactone (C12-AHL, CAS 8627-38-8, Sigma), N-tetradecanoyl-DL-homoserine lactone (C14-AHL, CAS 98206-80-5, Sigma), N-(3-hydroxydodecanoyl)-DLhomoserine (3-OH-C12-AHL, CAS 182359-60-0), and N-(3-hydroxytetradecanoyl)-DL-homoserine lactone (3-OH-C14-AHL, CAS 172670-99-4) at $5 \mu \mathrm{M}$ per compound or (3) DMSO for the control assay. DMSO was used as solvent for signal compound stock solutions. After inoculation, $32 \mathrm{mM}$ iron(II)-ions were added. The assay flasks were incubated for $2 \mathrm{~h}$ at $37^{\circ} \mathrm{C}$ with agitation at $140 \mathrm{rpm}$ and periodically sampled for determination of iron(II) concentrations using the phenanthroline method ${ }^{65}$. Within this time, the inhibitory effect of DSF/ BDSF on iron(II) oxidation was confirmed and subsequently the flasks were rapidly cooled on ice and by addition of 1 volume ice-cold Mac medium ( $\mathrm{pH} 1.8$ ). The cultures ( $n=4$ per condition) were centrifuged at $12,500 \times g$ for $10 \mathrm{~min}$ at $4{ }^{\circ} \mathrm{C}$. The resulting cell pellet was washed twice by re-suspending in $2 \mathrm{~mL}$ of sterile, ice-cold Mac medium ( $\mathrm{pH}$ 1.8) and then flash frozen in liquid nitrogen and stored at $-80^{\circ} \mathrm{C}$.

Nucleic acid extraction was conducted as described ${ }^{67}$ with modifications. Briefly, the cells were re-suspended in lysis buffer $(0.02 \%$ sodium acetate, $2 \%$ sodium dodecyl sulfate, $1 \mathrm{mM}$ EDTA, pH 5.5) and lysed using Trireagent (Ambion) and the lysate was treated with bromo-chloro propane. Nucleic acids were precipitated with isopropanol, cleaned with $80 \%$ ethanol, dried at room temperature, and subsequently treated with DNAse I (Thermo Fisher Scientific ${ }^{\circledast}$ ). Ribosomal RNA depletion was conducted using the QIAseq ${ }^{\circledast}$ FastSelect $^{\text {Tix }}-5$ S/16S/23S kit for bacterial RNA samples. Nucleic acid quantification and quality control were assessed by agarose gel electrophoresis, NanoDrop, Qubit ${ }^{\mathrm{Ti}}$ RNA HS Assay kit (Invitrogen $^{\oplus}$ ), and the Agilent 2100 Bioanalyzer. Libraries (12 in total) were prepared by SciLifeLab, Stockholm, Sweden using the Illumina TruSeq stranded mRNA Kit. Paired-end sequencing $(2 \times 151 \mathrm{bp})$ was performed on one Illumina NovaSeq6000 lane using 'NovaSeqXp' workflow in 'S4' mode flowcell.

Bioinformatics and statistics. The Bcl to FastQ conversion was performed using bcl2fastq_v2.20.0.422 from the CASAVA software suite. The quality scale used was Sanger/phred33/Illumina 1.8+. at SciLifeLab, Stockholm, Sweden. The quality of the raw sequencing reads was assessed with FastQC/MultiQC ${ }^{68,69}$. Subsequently, adapter sequences were removed using Cutadapt/TrimGalore 0.6.1 ${ }^{70,71}$. Paired-end transcript reads were mapped against the reference genome with the accession number GCA_900198525 $5^{38}$ using Bowtie $2^{72}$, sorted by their genomic location using the Samtools sort function, and counted using FeatureCounts of the Rsubreads package ${ }^{73}$. Raw counts were then processed for assessment of statistically significant differential gene expression with DESeq $2^{74}$ by determination of LFC and corresponding $p$ values ( $p$ adj, adjusted $p$ values $<0.05$ ). Differentially expressed genes $(|\mathrm{LFC}|>1, p a d j<0.05)$ were analyzed using the clusters of orthologous groups (COG) database $\mathrm{F}^{75}$.

\section{Data availability}

The raw sequencing data for the twelve axenic culture samples were deposited in ArrayExpress at the European Bioinformatics Institute under the accession E-MTAB-9845.

Received: 10 May 2021; Accepted: 21 July 2021

Published online: 11 August 2021

\section{References}

1. Brierley, C. L. \& Brierley, J. A. Progress in bioleaching: part B: applications of microbial processes by the minerals industries. Appl. Microbiol. Biotechnol. 97, 7543-7552. https://doi.org/10.1007/s00253-013-5095-3 (2013).

2. Vera, M., Schippers, A. \& Sand, W. Progress in bioleaching: fundamentals and mechanisms of bacterial metal sulfide oxidation part A. Appl. Microbiol. Biotechnol. 97, 7529-7541. https://doi.org/10.1007/s00253-013-4954-2 (2013).

3. Bond, P. L., Druschel, G. K. \& Banfield, J. F. Comparison of acid mine drainage microbial communities in physically and geochemically distinct ecosystems. Appl. Environ. Microbiol. 66, 4962-4971. https://doi.org/10.1128/AEM.66.11.4962-4971.2000 (2000).

4. Bond, P. L., Smriga, S. P. \& Banfield, J. F. Phylogeny of microorganisms populating a thick, subaerial, predominantly lithotrophic biofilm at an extreme acid mine drainage site. Appl. Environ. Microbiol. 66, 3842-3849. https://doi.org/10.1128/AEM.66.9.38423849.2000 (2000).

5. Coram, N. J. \& Rawlings, D. E. Molecular relationship between two groups of the genus Leptospirillum and the finding that Leptospirillum ferriphilum sp. Nov. dominates South African commercial biooxidation tanks that operate at $40^{\circ} \mathrm{C}$. Appl. Environ. Microbiol. 68, 838-845. https://doi.org/10.1128/AEM.68.2.838-845.2002 (2002).

6. Wilmes, P. et al. Natural acidophilic biofilm communities reflect distinct organismal and functional organization. ISME J. 3, 266-270. https://doi.org/10.1038/ismej.2008.90 (2009).

7. Norris, P. R., Barr, D. W. \& Hinson, D. Iron and mineral oxidation by acidophilic bacteria: Affinities for iron and attachment to pyrite in Biohydrometallurgy Proc Int Symp (ed. Kelly, D. P.) 43-59 (Warwick, 1988).

8. Rawlings, D. E., Tributsch, H. \& Hansford, G. S. Reasons why 'Leptospirillum'-like species rather than Thiobacillus ferrooxidans are the dominant iron-oxidizing bacteria in many commercial processes for the biooxidation of pyrite and related ores. Microbiology 145, 5-13 (1999).

9. Acosta, M. et al. Variation in microbial community from predominantly mesophilic to thermotolerant and moderately thermophilic species in an industrial copper heap bioleaching operation. Hydrometallurgy 150, 281-289. https://doi.org/10.1016/j.hydromet. 2014.09.010 (2014). 
10. Sand, W., Gehrke, T., Jozsa, P.G. \& Schippers, A. (Bio)chemistry of bacterial leaching - direct vs. indirect bioleaching. Hydrometallurgy 59, 159-175. https://doi.org/10.1016/S0304-386X(00)00180-8 (2001).

11. Zhang, R., Bellenberg, S., Neu, T. R., Sand, W. \& Vera, M. The biofilm lifestyle of acidophilic metal/sulfur-oxidizing microorganisms. Biotechnol. Extremophiles. https://doi.org/10.1007/978-3-319-13521-2_6 (2016).

12. Harneit, K. et al. Adhesion to metal sulfide surfaces by cells of Acidithiobacillus ferrooxidans, Acidithiobacillus thiooxidans and Leptospirillum ferrooxidans. Hydrometallurgy 83, 245-254. https://doi.org/10.1016/j.hydromet.2006.03.044 (2006).

13. Rohwerder, T. \& Sand, W. Mechanisms and biochemical fundamentals of bacterial metal sulfide oxidation in Microbial Processing of Metal Sulfides (eds. Donati E.R. \& Sand W.) 35-58 (Springer, 2007).

14. Bellenberg, S. et al. Manipulation of pyrite colonization and leaching by iron-oxidizing Acidithiobacillus species. Appl. Microbiol. Biotechnol. 99, 1435-1449. https://doi.org/10.1007/s00253-014-6180-y (2015).

15. Bellenberg, S. et al. Automated microscopic analysis of metal sulfide colonization by acidophilic microorganisms. Appl. Environ. Microbiol. https://doi.org/10.1128/AEM.01835-18 (2018).

16. Gehrke, T., Telegdi, J., Thierry, D. \& Sand, W. Importance of extracellular polymeric substances from Thiobacillus ferrooxidans for bioleaching. Appl. Environ. Microbiol. 64, 2743-2747. https://doi.org/10.1128/AEM.64.7.2743-2747.1998 (1998).

17. Gehrke, T., Hallmann, R., Kinzler, K. \& Sand, W. The EPS of Acidithiobacillus ferrooxidans-a model for structure-function relationships of attached bacteria and their physiology. Water Sci. Technol. 43, 159-167. https://doi.org/10.2166/wst.2001.0365 (2001).

18. Waters, C. M. \& Bassler, B. L. Quorum sensing: cell-to-cell communication in bacteria. Annu. Rev. Cell. Dev. Biol. 21, 319-346. https://doi.org/10.1146/annurev.cellbio.21.012704.131001 (2005).

19. Farah, C. et al. Evidence for a functional quorum-sensing type AI-1 system in the extremophilic bacterium Acidithiobacillus ferrooxidans. Appl. Environ. Microbiol. 71, 7033-7040. https://doi.org/10.1128/AEM.71.11.7033-7040.2005 (2005).

20. Bellenberg, S. et al. Biofilm formation, communication and interactions of leaching bacteria during colonization of pyrite and sulfur surfaces. Res. Microbiol. 165, 773-781. https://doi.org/10.1016/j.resmic.2014.08.006 (2014).

21. Rivas, M., Seeger, M., Holmes, D. S. \& Jedlicki, E. A Lux-like quorum sensing system in the extreme acidophile Acidithiobacillus ferrooxidans. Biol. Res. 38, 283-297. https://doi.org/10.4067/S0716-97602005000200018 (2005).

22. Valenzuela, S., Banderas, A., Jerez, C. A. \& Guiliani, N. Cell-Cell Communication In Bacteria in Microbial Processing of Metal Sulfides (eds. Donati E.R. \& Sand W.) 253-264 (Springer,2007).

23. Bellenberg, S., Leon-Morales, C.-F., Sand, W. \& Vera, M. Visualization of capsular polysaccharide induction in Acidithiobacillus ferrooxidans. Hydrometallurgy 129, 82-89. https://doi.org/10.1016/j.hydromet.2012.09.002 (2012).

24. González, A. et al. AHL signaling molecules with a large acyl chain enhance biofilm formation on sulfur and metal sulfides by the bioleaching bacterium Acidithiobacillus ferrooxidans. Appl. Microbiol. Biotechnol. 97, 3729-3737. https://doi.org/10.1007/s00253012-4229-3 (2013).

25. Mamani, S. et al. Insights into the quorum sensing regulon of the acidophilic Acidithiobacillus ferrooxidans revealed by transcriptomic in the presence of an acyl homoserine lactone superagonist analog. Front. Microbiol. 7, 1365. https://doi.org/10.3389/fmicb. 2016.01365 (2016).

26. Ruiz, L. M. et al. AHL communication is a widespread phenomenon in biomining bacteria and seems to be involved in mineraladhesion efficiency. Hydrometallurgy 94, 133-137. https://doi.org/10.1016/j.hydromet.2008.05.028 (2008).

27. Hengge, R. Principles of c-di-GMP signalling in bacteria. Nat. Rev. Microbiol. 7, 263-273. https://doi.org/10.1038/nrmicro2109 (2009).

28. Moya-Beltrán, A. et al. Nucleotide second messenger-based signaling in extreme acidophiles of the Acidithiobacillus species complex: Partition between the core and variable gene complements. Front. Microbiol. 10, 381. https://doi.org/10.3389/fmicb.2019. 00381 (2019).

29. Castro, M., Díaz, M., Beltrán, A. M. \& Guiliani, N. Cyclic di-GMP Signaling in extreme acidophilic bacteria in Microbial Cyclic Di-Nucleotide Signaling (eds. Chou, S.H., Guiliani, N., Lee, V. \& Römling, U.) 337-353 (Springer, Cham., 2020).

30. Ruiz, L., Castro, M., Barriga, A., Jerez, C. \& Guiliani, N. The extremophile Acidithiobacillus ferrooxidans possesses a c-di-GMP signalling pathway that could play a significant role during bioleaching of minerals. Lett. Appl. Microbiol. 54, 133-139. https://doi. org/10.1111/j.1472-765X.2011.03180.x (2011).

31. Issotta, F. et al. Insights into the biology of acidophilic members of the Acidiferrobacteraceae family derived from comparative genomic analyses. Res. Microbiol. 169, 608-617. https://doi.org/10.1016/j.resmic.2018.08.001 (2018).

32. Ryan, R. P., An, S.-Q., Allan, J. H., McCarthy, Y. \& Dow, J. M. The DSF family of cell-cell signals: an expanding class of bacterial virulence regulators. PLoS Pathog. 11, e1004986. https://doi.org/10.1371/journal.ppat.1004986 (2015).

33. Zhou, L., Zhang, L.-H., Cámara, M. \& He, Y.-W. The DSF family of quorum sensing signals: diversity, biosynthesis, and turnover. Trends Microbiol. 25, 293-303. https://doi.org/10.1016/j.tim.2016.11.013 (2017).

34. Wang, L.-H. et al. A bacterial cell-cell communication signal with cross-kingdom structural analogues. Mol. Microbiol. 51, 903-912. https://doi.org/10.1046/j.1365-2958.2003.03883.x (2004).

35. Davies, D. G. \& Marques, C. N. A fatty acid messenger is responsible for inducing dispersion in microbial biofilms. J. Bacteriol. 191, 1393-1403. https://doi.org/10.1128/JB.01214-08 (2009).

36. Ryan, R. P. \& Dow, J. M. Communication with a growing family: diffusible signal factor (DSF) signaling in bacteria. Trends Microbiol. 19, 145-152. https://doi.org/10.1016/j.tim.2010.12.003 (2011).

37. Dean, S. N., Chung, M.-C. \& van Hoek, M. L. Burkholderia diffusible signal factor signals to Francisella novicida to disperse biofilm and increase siderophore production. Appl. Environ. Microbiol. 81, 7057-7066. https://doi.org/10.1128/AEM.02165-15 (2015).

38. Christel, S. et al. Multi-omics reveals the lifestyle of the acidophilic, mineral-oxidizing model species Leptospirillum ferriphilum ${ }^{\mathrm{T}}$. Appl. Environ. Microbiol. https://doi.org/10.1128/AEM.02091-17 (2017).

39. Buetti-Dinh, A. et al. Systems biology of acidophile biofilms for efficient metal extraction. Sci. Data 7, 1-10. https://doi.org/10. 1038/s41597-020-0519-2 (2020).

40. Fujimura, R. et al. Complete genome sequence of Leptospirillum ferrooxidans strain C2-3, isolated from a fresh volcanic ash deposit on the island of Miyake, Japan. J. Bacteriol. 194, 4122-4123. https://doi.org/10.1128/JB.00696-12 (2012).

41. Suppiger, A., Aguilar, C. \& Eberl, L. Evidence for the widespread production of DSF family signal molecules by members of the genus Burkholderia by the aid of novel biosensors. Environ. Microbiol. Rep. 8, 38-44. https://doi.org/10.1111/1758-2229.12348 (2016).

42. Li, Q. et al. Interactions between cells of Sulfobacillus thermosulfidooxidans and Leptospirillum ferriphilum during pyrite bioleaching. Front. Microbiol. 11, 44. https://doi.org/10.3389/fmicb.2020.00044 (2020).

43. Christel, S. et al. Weak iron oxidation by Sulfobacillus thermosulfidooxidans maintains a favorable redox potential for chalcopyrite bioleaching. Front. Microbiol. https://doi.org/10.3389/fmicb.2018.03059 (2018).

44. Noël, N. Attachment of acidophilic bacteria to solid substrata. Ph.D.thesis. (Universität Duisburg-Essen, Duisburg, Germany, 2013).

45. Tuttle, J., Dugan, P. R. \& Apel, W. A. Leakage of cellular material from Thiobacillus ferrooxidans in the presence of organic acids. Appl. Environ. Microbiol. 33, 459-469 (1977).

46. Onysko, S. J., Kleinmann, R. L. \& Erickson, P. M. Ferrous iron oxidation by Thiobacillus ferrooxidans: inhibition with benzoic acid, sorbic acid, and sodium lauryl sulfate. Appl. Environ. Microbiol. 48, 229-231 (1984). 
47. Alexander, B., Leach, S. \& Ingledew, W. J. The relationship between chemiosmotic parameters and sensitivity to anions and organic acids in the acidophile Thiobacillus ferrooxidans. Microbiology 133, 1171-1179. https://doi.org/10.1099/00221287-133-5-1171 (1987).

48. Frattini, C., Leduc, L. \& Ferroni, G. Strain variability and the effects of organic compounds on the growth of the chemolithotrophic bacterium Thiobacillus ferrooxidans. Antonie Van Leeuwenhoek 77, 57-64. https://doi.org/10.1023/A:1002089001725 (2000).

49. Aston, J. E., Apel, W. A., Lee, B. D. \& Peyton, B. M. Toxicity of select organic acids to the slightly thermophilic acidophile Acidithiobacillus caldus. Environ. Toxicol. Chem. 28, 279-286. https://doi.org/10.1897/08-277.1 (2009).

50. Nancucheo, I. \& Johnson, D. B. Production of glycolic acid by chemolithotrophic iron-and sulfur-oxidizing bacteria and its role in delineating and sustaining acidophilic sulfide mineral-oxidizing consortia. Appl. Environ. Microbiol. 76, 461-467. https://doi. org/10.1128/AEM.01832-09 (2009).

51. Huang, C. B., Alimova, Y., Myers, T. M. \& Ebersole, J. L. Short-and medium-chain fatty acids exhibit antimicrobial activity for oral microorganisms. Arch. Oral Biol. 56, 650-654. https://doi.org/10.1016/j.archoralbio.2011.01.011 (2011).

52. Rinzema, A., Boone, M., van Knippenberg, K. \& Lettinga, G. Bactericidal effect of long chain fatty acids in anaerobic digestion. Water Environ. Res. 66, 40-49. https://doi.org/10.2175/WER.66.1.7Citations:164 (1994).

53. Silva, S. A. et al. Toxicity of long chain fatty acids towards acetate conversion by Methanosaeta concilii and Methanosarcina mazei. Microb. Biotechnol. 9, 514-518. https://doi.org/10.1111/1751-7915.12365 (2016).

54. Parsons, J. B., Yao, J., Frank, M. W., Jackson, P. \& Rock, C. O. Membrane disruption by antimicrobial fatty acids releases lowmolecular-weight proteins from Staphylococcus aureus. J. Bacteriol. 194, 5294-5304. https://doi.org/10.1128/JB.00743-12 (2012).

55. Luo, G. et al. flrA, flrB and $\mathrm{flrC}$ regulate adhesion by controlling the expression of critical virulence genes in Vibrio alginolyticus. Emerg. Microb. Infect. 5, 1-11. https://doi.org/10.1038/emi.2016.82 (2016).

56. He, Y.-W. et al. Genome scale analysis of diffusible signal factor regulon in Xanthomonas campestris pv. campestris: identification of novel cell-cell communication-dependent genes and functions. Mol. Microbiol. 59, 610-622. https://doi.org/10.1111/j.1365-2958. 2005.04961.x (2006).

57. Malamud, F. et al. The Xanthomonas axonopodis pv. citri flagellum is required for mature biofilm and canker development. Microbiology 157, 819-829. https://doi.org/10.1099/mic.0.044255-0 (2011).

58. Suppiger, A. et al. The DSF type quorum sensing signalling system RpfF/R regulates diverse phenotypes in the opportunistic pathogen Cronobacter. Sci. Rep. 6, 1-8. https://doi.org/10.1038/srep18753 (2016).

59. Tuckerman, J. R. et al. An oxygen-sensing diguanylate cyclase and phosphodiesterase couple for c-di-GMP control. Biochemistry 48, 9764-9774. https://doi.org/10.1021/bi901409g (2009).

60. Schluchter, W. M., Zhao, J. \& Bryant, D. A. Isolation and characterization of the ndhF gene of Synechococcus sp. strain PCC 7002 and initial characterization of an interposon mutant. J. Bacteriol. 175, 3343-3352. https://doi.org/10.1128/jb.175.11.3343-3352. 1993 (1993)

61. Lioliou, E. E. et al. Phosphorylation activity of the response regulator of the two-component signal transduction system atoS-atoC in E. coli. Biochim. Biophys. Acta Gen. Subj. 1725, 257-268, https://doi.org/10.1016/j.bbagen.2005.06.019 (2005).

62. Wang, C., Delcros, J., Cannon, L., Konate, F. \& Carias, H. Defining the molecular requirements for the selective delivery of polyamine conjugates into cells containing active polyamine transporters. J. Med. Chem. 46, 5129-5138. https://doi.org/10.1021/jm030 223a (2003).

63. Theodorou, M. C., Theodorou, E. C. \& Kyriakidis, D. A. Involvement of atoSC two-component system in Escherichia coli flagellar regulon. Amino Acids 43, 833-844. https://doi.org/10.1007/s00726-011-1140-7 (2012).

64. Mackintosh, M. E. Nitrogen fixation by Thiobacillus ferrooxidans. Microbiology 105, 215-218. https://doi.org/10.1099/00221287$105-2-215$ (1978).

65. Harvey, A. E. Jr., Smart, J. A. \& Amis, E. Simultaneous spectrophotometric determination of iron (II) and total iron with 1, 10-phenanthroline. Anal. Chem. 27, 26-29. https://doi.org/10.1021/ac60097a009 (1955)

66. Schippers, A. \& Sand, W. Bacterial leaching of metal sulfides proceeds by two indirect mechanisms via thiosulfate or via polysulfides and sulfur. Appl. Environ. Microbiol. 65, 319-321. https://doi.org/10.1128/AEM.65.1.319-321.1999 (1999).

67. Christel, S., Fridlund, J., Watkin, E. L. \& Dopson, M. Acidithiobacillus ferrivorans SS3 presents little RNA transcript response related to cold stress during growth at $8^{\circ} \mathrm{C}$ suggesting it is a eurypsychrophile. Extremophiles 20, 903-913. https://doi.org/10.1007/ s00792-016-0882-2 (2016).

68. Andrews, S. FastQC: a quality control tool for high throughput sequence data. Version 0.11. 2. Website: http://www.bioinformatics. babraham.ac.uk/projects/fastqc (2010).

69. Ewels, P., Magnusson, M., Lundin, S. \& Käller, M. MultiQC: summarize analysis results for multiple tools and samples in a single report. Bioinformatics 32, 3047-3048. https://doi.org/10.1093/bioinformatics/btw354 (2016).

70. Martin, M. Cutadapt removes adapter sequences from high-throughput sequencing reads. EMBnet J. 17, 10-12. https://doi.org/ 10.14806/ej.17.1.200 (2011).

71. Krueger, F. et al. A wrapper tool around Cutadapt and FastQC to consistently apply quality and adapter trimming to FastQ files. Cambridge, UK: Babraham Institute (2015).

72. Langmead, B. \& Salzberg, S. L. Fast gapped-read alignment with Bowtie 2. Nat Methods 9, 357. https://doi.org/10.1038/nmeth. 1923 (2012).

73. Liao, Y., Smyth, G. K. \& Shi, W. The R package Rsubread is easier, faster, cheaper and better for alignment and quantification of RNA sequencing reads. Nucleic Acids Res. 47, e47-e47. https://doi.org/10.1093/nar/gkz114 (2019).

74. Love, M. I., Huber, W. \& Anders, S. Moderated estimation of fold change and dispersion for RNA-seq data with DESeq2. Genome Biol. 15, 1-21. https://doi.org/10.1186/s13059-014-0550-8 (2014).

75. Galperin, M. Y., Makarova, K. S., Wolf, Y. I. \& Koonin, E. V. Expanded microbial genome coverage and improved protein family annotation in the COG database. Nucleic Aacids Res 43, D261-D269. https://doi.org/10.1093/nar/gku1223 (2015).

\section{Acknowledgements}

Carlotta Fabbri and Leo Eberl (Department of Plant and Microbial Biology, University of Zurich, Zurich, Switzerland) kindly provided the biosensor strain Burkholderia cenocepacia $\mathrm{H} 111-\mathrm{rpfF}_{B c}$ (pan-L15). Michael Schlömann (Institute of Biosciences, Environmental Microbiology Group, Technische Universität Bergakademie Freiberg) kindly provided access to the GC-MS instrument. We acknowledge support from the National Genomics Infrastructure in Stockholm funded by Science for Life Laboratory, the Knut and Alice Wallenberg Foundation and the Swedish Research Council, and SNIC/Uppsala Multidisciplinary Center for Advanced Computational Science for assistance with massively parallel sequencing and access to the UPPMAX computational infrastructure.

\section{Author contributions}

S.B., M.V., and M.D. conceived the study. S.B., B.S., and C.J. carried out the microbiological experiments. S.G. and S.B. conducted GC-MS experiments. S.G., C.R.U., and M.L.V. analysed GC-MS data. S.B. prepared and 
S.B., A.B., B.S. and M.V. analyzed the RNA sequencing data. S.B., B.S., M.V., and M.D. drafted the manuscript that was approved by all authors.

\section{Funding}

Mark Dopson and Mario Vera acknowledge funding from the Swedish Innovation Agency (Vinnova) and the Agencia Nacional de Investigación y Desarrollo (ANID), respectively under ERA-MIN 2 supported by the European Commission, via the project Microbial Consortia for enhanced Copper Recovery (MiCCuR). Sören Bellenberg acknowledges funding from DFG (BE 6668/1-1). MV acknowledges funding from FONDECYT/ ANID 1190892 grant. Beatriz Salas acknowledges support from CONICYT/ANID PhD Scolarship 21200461.

\section{Competing interests}

The authors declare no competing interests.

\section{Additional information}

Supplementary Information The online version contains supplementary material available at https://doi.org/ 10.1038/s41598-021-95324-9.

Correspondence and requests for materials should be addressed to S.B. or M.V.

Reprints and permissions information is available at www.nature.com/reprints.

Publisher's note Springer Nature remains neutral with regard to jurisdictional claims in published maps and institutional affiliations.

(c) (i) Open Access This article is licensed under a Creative Commons Attribution 4.0 International License, which permits use, sharing, adaptation, distribution and reproduction in any medium or format, as long as you give appropriate credit to the original author(s) and the source, provide a link to the Creative Commons licence, and indicate if changes were made. The images or other third party material in this article are included in the article's Creative Commons licence, unless indicated otherwise in a credit line to the material. If material is not included in the article's Creative Commons licence and your intended use is not permitted by statutory regulation or exceeds the permitted use, you will need to obtain permission directly from the copyright holder. To view a copy of this licence, visit http://creativecommons.org/licenses/by/4.0/.

(C) The Author(s) 2021 